\title{
ASSESSMENT OF Passiflora vitifolia LEAVES EXTRACT AS A POTENTIAL INHIBITOR FOR MILD STEEL ACID CORROSION
}

\author{
R. Thilagavathi, A. Prithiba and R. Rajalakshmi* \\ Department of Chemistry, Avinashilingam Institute for Home Science and Higher Education for \\ Women, Coimbatore-641043,Tamil Nadu,India \\ *E-mail: rajivardhan@gmail.com
}

\begin{abstract}
The present study is focused on the application of Passiflora vitifolia leaves to extract as an inhibitor for corrosion of mild steel in 1M hydrochloric acid solution. Mass loss measurements reflect an inhibition efficiency of $97.1 \%$ at $12 \mathrm{~h}$ of immersion and electrochemical measurement afforded a protection efficiency of $89.8 \%$ at $0.7 \%$ concentration of the inhibitor. The adsorption of the Passiflora vitifolia leaves extract onto the mild steel surface obeyed Langmuir adsorption isotherm. Thermodynamic parameters were also calculated and discussed. Potentiodynamic polarization implied that Passiflora vitifolia leaves extract in $1 \mathrm{M} \mathrm{HCl}$ behaved as mixed type inhibitor. The Nyquist plots reflected an increase in charge transfer resistance and decreased double layer capacitance with an increase in additive dosage. Surface morphological studies further implied the effectiveness of the inhibitor under study.

Keywords: Passiflora vitifolia Leaves, Corrosion Inhibition, Mass Loss, Electrochemical Study, Surface Morphology.
\end{abstract}

() RASĀYAN. All rights reserved

\section{INTRODUCTION}

The serious consequences of corrosion, a naturally occurring phenomenon, tend to jeopardize the safety of metals and inhibit technology progress as metals place a vital role in the world economy. Among the acidic solutions, hydrochloric acid is the commonly used agent ${ }^{1}$ - in industries to remove rust from the mild steel surface. This tends to considerable damage to the metal surface. Literature reports that several synthetic compounds have shown good anticorrosive activity but these inhibitors may cause reversible and irreversible damage to organ system viz., kidneys or liver, or to disturb a biochemical process or to disturb an enzyme system at some site in the body ${ }^{2}$. The toxicity may manifest either during the synthesis of the compound or during its applications. These toxic effects have led to the use of natural products as anti-corrosion agents which are eco-friendly and harmless. For this reason, plant extracts have attracted the attention of researchers as ecologically acceptable corrosion inhibitors. Hence the present work is proposed to evaluate the inhibitive nature of the selected plant extracts as an inhibitor for mild steel corrosion in $1 \mathrm{M} \mathrm{HCl}$. Our research team has carried out several studies successfully in utilizing natural products for mild steel corrosion inhibitor ${ }^{3-15}$.

Passiflora species have been widely investigated for the presence of bioactive compounds in all the plant organs, including leaves, flowers, fruits and seeds, and a series of flavonoids, glycosides, alkaloids, and phenols have been reported ${ }^{16-29}$. Based on the above literature survey, the present study focuses on corrosion mitigation of MS in 1M HCl using Passiflora vitifolia leaves extract.

\section{EXPERIMENTAL}

\section{Material Selection}

The selected MS specimen for the present study comprised of (weight \%) - carbon $0.019 \%$, manganese $0.352 \%$, silicon $0.049 \%$, phosphorus $0.019 \%$, sulphur $0.013 \%$, chromium $0.010 \%$, molybdenum $0.008 \%$,

Rasayan J. Chem., 12(2), 431-449(2019)

http://dx.doi.org/10.31788/RJC.2019.1225133

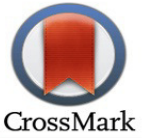


nickel $0.010 \%$, Copper $0.026 \%$ and iron $99.33 \%$. The coupons having dimension of $1 \mathrm{~cm}^{2}$ were used for electrochemical technique and $1 \times 5 \mathrm{~cm}^{2}$ was used for mass loss method. The specimens were prepared as per the procedure reported [ASTM G1-03] ${ }^{30}$.

\section{Preparation of Plant Extract}

Passiflora vitifolia leaves (PAVL) were collected from the Maruthamalai area in Coimbatore and shade dried. The plant specimen was authenticated in Botanical Survey of India (BSI/SRC/5/23/20122018/Tech/1742). $500 \mathrm{~mL}$ of 1 molar hydrochloric acid was added with $25 \mathrm{~g}$ of powdered leaves and refluxed for 3 hours. The extract was kept overnight for cooling, then filtered and made up to $500 \mathrm{~mL}$ (5\% extract).

\section{Experimental Techniques \\ Mass Loss Method}

Pre-weighed mild steel sample was immersed in $100 \mathrm{~mL}$ of the blank/inhibitor solution for a prearranged time period as per ASTM G 1-2 ${ }^{31}$. After a predetermined test period, the MS specimens were washed, dried and reweighed.

\section{Electrochemical Measurements}

Potentiodynamic measurement and EIS measurements were performed using a Frequency response analyzer (Biologic model V10.23) in a three-electrode setup. Platinum, saturated calomel electrode and mild steel were employed as an auxiliary, reference and working electrodes respectively. For polarisation studies, the measurements were undertaken by applying a potential range of $-0.1 \mathrm{v}$ to $-1 \mathrm{mV}$ and scan rate of $2 \mathrm{mVs}^{-1}$. For EIS studies, a frequency range of $20 \mathrm{kHz}$ to $0.1 \mathrm{~Hz}$ at the OCP of the working electrode was applied.

\section{Surface Analytical Techniques FT-IR Spectroscopy}

FTIR was recorded using Shimadzu IR Affinity-1S Fourier Transform Infrared Spectrometer which extended from 4000 and $400 \mathrm{~cm}^{-1}$. It was performed to identify the functional groups present in the plant extract, while that of the corrosion products was done to ascertain the interaction between the metal and the extract.

\section{UV-Visible Spectrophotometer}

The investigated plants and corrosion product were subjected to UV-vis spectrophotometric characterization over 200-800 nm using AU-2701 UV-Vis Double beam spectrophotometer.

\section{D Optical Profilometer}

Surface profiles and pores were studied using 3D Optical Profilometer. The MS specimen exposed in 1M hydrochloric acid solution with and without the addition of PAVL extract for $3 \mathrm{~h}$ was examined by Zeta 3D Profiler. The specimens were mounted the sample holder and 3D images were taken with 100x magnified surface using operating program on the computer.

\section{SEM and EDX}

The surface topography of the metal surface in the absence and presence of PAVL extract was examined by SEM (JEOL MODEL JSM 6360). The nature of the formed protective film on MS surface was found out by EDX spectra.

\section{Characterization of the Investigated Inhibitor} Phytochemical Screening of PAVL Extract

HPTLC, FT-IR and UV techniques were performed to characterize the PAVL extract. Standard procedures were used to determine the phytochemical constituents present in the plant extract ${ }^{32}$. 
HPTLC Technique

CAMAG HPTLC instrument with Win CATS version 1.3.4 software was performed to analyze phytochemical components and its derivatives present in the leaf extract.

\section{FTIR Spectroscopy}

The inhibitor was characterized by FT-IR spectroscopy for identification of active functional groups. The FT-IR study was carried out by using Shimadzu IR Affinity-1S Fourier Transform Infrared Spectrometer.

\section{UV-Visible Spectrophotometer}

UV-Vis spectral studies of the investigated plant extract were done using AU-2701 UV-Vis Double beam spectrophotometer.

\section{Mass Loss Study}

\section{RESULTS AND DISCUSSION}

The effect of PAVL extract on the inhibition of MS corrosion was tested by mass loss measurement. Table-1, Fig.-1 indicated the variation of corrosion rate (CR) and inhibition efficiency (IE) with an increase in the concentration of PAVL extract. The corrosion rate decreased with increased concentration of the PAVL extract. The IE increased from $92.3 \%$ to $97.1 \%$ for $0.7 \%$ concentration of PAVL extract.

Table-1: Inhibition Efficiency of Mild Steel in $1 \mathrm{M} \mathrm{HCl}$ in the Presence and Absence of PAVL

\begin{tabular}{c|c|c|c|c|c|c|c|c|c|c|c|c}
\hline \multirow{2}{*}{$\begin{array}{c}\text { Conc } \\
(\% \mathrm{v} / \mathrm{v})\end{array}$} & $\begin{array}{c}\mathrm{CR} \\
(\mathrm{mpy})\end{array}$ & $\begin{array}{c}\mathrm{IE} \\
(\%)\end{array}$ & $\begin{array}{c}\mathrm{CR} \\
(\mathrm{mpy})\end{array}$ & $\begin{array}{c}\mathrm{IE} \\
(\%)\end{array}$ & $\begin{array}{c}\mathrm{CR} \\
(\mathrm{mpy})\end{array}$ & $\begin{array}{c}\text { IE } \\
(\%)\end{array}$ & $\begin{array}{c}\mathrm{CR} \\
(\mathrm{mpy})\end{array}$ & $\begin{array}{c}\text { IE } \\
(\%)\end{array}$ & $\begin{array}{c}\text { CR } \\
(\mathrm{mpy})\end{array}$ & $\begin{array}{c}\text { IE } \\
(\%)\end{array}$ & $\begin{array}{c}\text { CR } \\
(\mathrm{mpy})\end{array}$ & $\begin{array}{c}\text { IE } \\
(\%)\end{array}$ \\
\hline Blank & 4538 & - & 4405 & - & 2706 & - & 2625 & - & 2123 & - & 1707 & - \\
\hline 0.1 & 623 & 86.3 & 431 & 90.2 & 269 & 90.1 & 195 & 92.6 & 148 & 93.0 & 157 & 90.8 \\
\hline 0.2 & 537 & 88.2 & 320 & 92.7 & 191 & 93.0 & 142 & 94.6 & 96 & 95.5 & 108 & 93.7 \\
\hline 0.3 & 469 & 89.7 & 303 & 93.1 & 159 & 94.1 & 126 & 95.2 & 78 & 96.3 & 103 & 94.0 \\
\hline 0.4 & 409 & 91.0 & 282 & 93.6 & 137 & 95.0 & 109 & 95.9 & 72 & 96.6 & 92 & 94.6 \\
\hline 0.5 & 384 & 91.5 & 256 & 94.2 & 131 & 95.2 & 94 & 96.4 & 64 & 97.0 & 91 & 94.7 \\
\hline 0.6 & 375 & 91.7 & 252 & 94.3 & 117 & 95.7 & 92 & 96.5 & 64 & 97.0 & 82 & 95.2 \\
\hline 0.7 & 350 & 92.3 & 235 & 94.7 & 112 & 95.8 & 82 & 96.9 & 63 & 97.1 & 79 & 95.4 \\
\hline
\end{tabular}

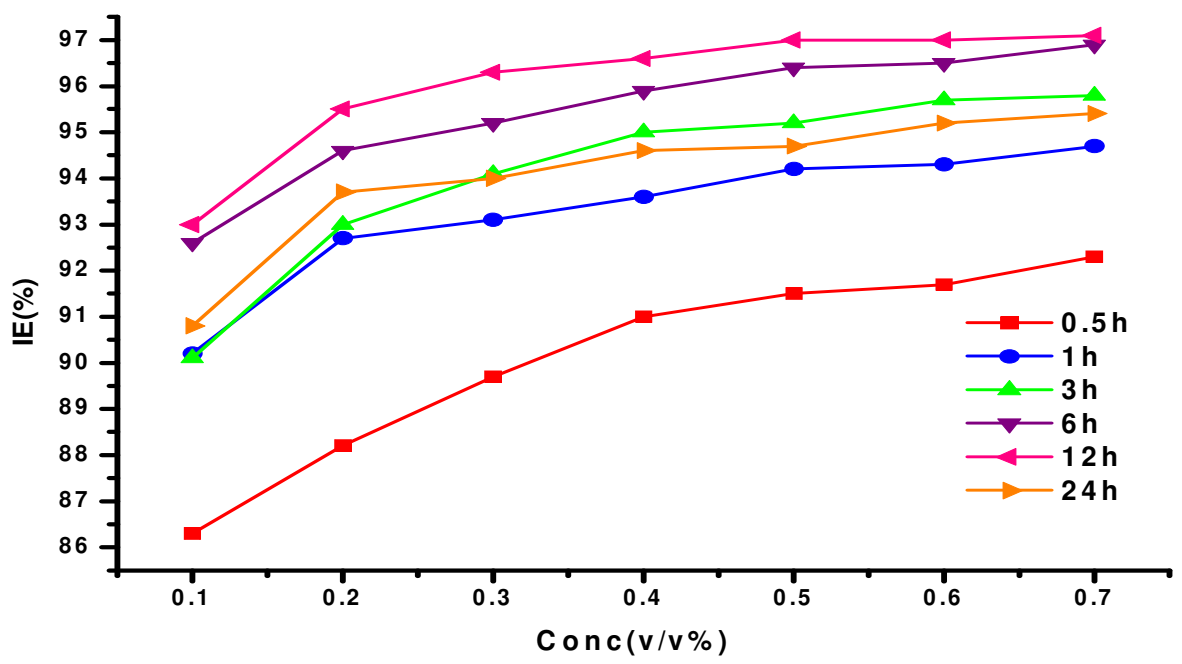

Figure. 1 Inhibition efficiency of PAVL on corrosion of MS in $1 \mathrm{M} \mathrm{HCl}$

An insight into the stability of PAVL extract with time may be gained by studying the effect of the extract on MS specimen for various time of immersion. The results evaluated for the variation of mass loss with 
RASĀYAN J. Chem.

Vol. 12 | No. 2 |431 - 449| April - June | 2019

exposure time for the MS specimen immersed in $1 \mathrm{M} \mathrm{HCl}$ with and without inhibitor are presented in Table-1. A maximum IE of $97.1 \%$ was maintained till $12 \mathrm{~h}$ and then a slight decline was observed. But the inhibition efficiency was found to stabilize at $24 \mathrm{~h}$ to afford an efficiency of $95.4 \%$ demonstrating the effectiveness of the inhibitor at longer periods of immersion.

\section{Effect of Temperature}

The effect of temperature on inhibition efficiency of PAVL extract in an acidic environment is depicted in Fig.-2. The corrosion rate decreased by increased in PAVL extract at any given temperature. Analyzing the temperature effect of PAVL, it can be noticed that the IE increased with increase in temperature up to $333 \mathrm{~K}$ giving rise to $94.0 \%$ and then a slight decrease was noticed from $333 \mathrm{~K}$ to $353 \mathrm{~K}$ which then stabilized to $90.8 \%$ at $353 \mathrm{~K}$. It was due to desorption of the adsorbed PAVL molecules at elevated temperatures ${ }^{33}$.

Table-2: Effect of Temperature on MS Specimen in Acidic Medium with and without Addition of PAVL Extract

\begin{tabular}{c|c|c|c|c|c|c|c|c|c|c|c|c}
\hline Conc & \multicolumn{2}{|c|}{$303 \mathrm{~K}$} & \multicolumn{2}{c|}{$313 \mathrm{~K}$} & \multicolumn{2}{c|}{$323 \mathrm{~K}$} & \multicolumn{2}{c|}{$333 \mathrm{~K}$} & \multicolumn{2}{c|}{$343 \mathrm{~K}$} & \multicolumn{2}{c}{$353 \mathrm{~K}$} \\
\cline { 2 - 13 }$(\% \mathrm{VR} / \mathrm{v})$ & $\begin{array}{c}\mathrm{CR} \\
(\mathrm{mpy})\end{array}$ & $\begin{array}{c}\text { IE } \\
(\%)\end{array}$ & $\begin{array}{c}\mathrm{CR} \\
(\mathrm{mpy})\end{array}$ & $\begin{array}{c}\text { IE } \\
(\%)\end{array}$ & $\begin{array}{c}\text { CR } \\
(\mathrm{mpy})\end{array}$ & $\begin{array}{c}\text { IE } \\
(\%)\end{array}$ & $\begin{array}{c}\text { CR } \\
(\mathrm{mpy})\end{array}$ & $\begin{array}{c}\text { IE } \\
(\%)\end{array}$ & $\begin{array}{c}\text { CR } \\
(\mathrm{mpy})\end{array}$ & $\begin{array}{c}\text { IE } \\
(\%)\end{array}$ & $\begin{array}{c}\text { CR } \\
(\mathrm{mpy})\end{array}$ & $\begin{array}{c}\text { IE } \\
(\%)\end{array}$ \\
\hline Blank & 4538 & - & 6585 & - & 9570 & - & 14884 & - & 20130 & - & 29819 & - \\
\hline 0.1 & 623 & 86.3 & 904 & 86.3 & 1416 & 85.2 & 2926 & 80.3 & 3796 & 81.1 & 7045 & 76.4 \\
\hline 0.2 & 537 & 88.2 & 768 & 88.3 & 1152 & 88.0 & 1680 & 88.7 & 2712 & 86.5 & 4862 & 83.7 \\
\hline 0.3 & 469 & 89.7 & 631 & 90.4 & 1007 & 89.5 & 1527 & 89.7 & 2337 & 88.4 & 4000 & 86.6 \\
\hline 0.4 & 409 & 91.0 & 546 & 91.7 & 904 & 90.6 & 1484 & 90.0 & 1970 & 90.2 & 3693 & 87.6 \\
\hline 0.5 & 384 & 91.5 & 546 & 91.7 & 836 & 91.3 & 1228 & 91.7 & 1732 & 91.4 & 3301 & 88.9 \\
\hline 0.6 & 375 & 91.7 & 478 & 92.7 & 725 & 92.4 & 1203 & 92.0 & 1612 & 92.0 & 3105 & 89.6 \\
\hline 0.7 & 350 & 92.3 & 461 & 93.0 & 682 & 92.9 & 887 & 94.0 & 1552 & 92.3 & 2755 & 90.8 \\
\hline
\end{tabular}

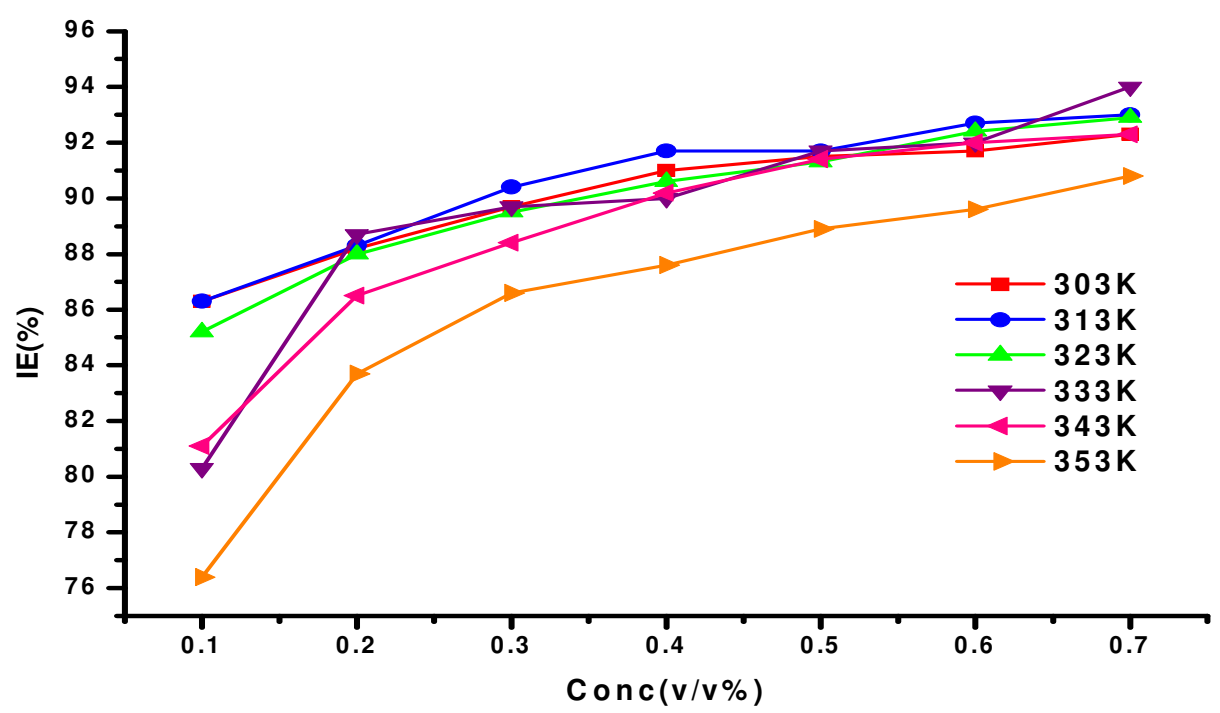

Fig.-2: Effect of Temperature on MS in Acidic Medium with and without PAVL Extract

\section{Energy of Activation}

The effect of corrosion rate on temperature can be regarded as an Arrhenius - type process, the rate of which is given by

$\log \mathrm{CR}=\log \mathrm{A}-\mathrm{E}_{\mathrm{a}} / 2.303 \mathrm{R}$

Where, CR is the corrosion rate of MS, A is Arrhenius constant, $E_{a}$ is the activation energy, $\mathrm{R}$ is the gas constant and $\mathrm{T}$ is the temperature. 
From the slope of Arrhenius plot (log CR vs. 1/T- Fig.-3a) $E_{a}$ values were obtained. Inspection of Table-3 revealed that the $E_{a}$ value increased with increase in PAVL extract. The $E_{a}$ values for the investigated inhibitor were found to be higher than the blank implying the increased energy barrier of the corrosion process due to the presence of PAVL extract. This was due to an electrostatic nature of the adsorbed inhibitor on the MS surface ${ }^{34,35}$. This inspection further supported the physical adsorption mechanism as reported. Several investigators observed lower the values of $E_{a}$ with and without the addition of an inhibitor solution were denoting the chemical adsorption mechanism, whereas the reverse statement reflected a physical adsorption mechanism ${ }^{36,37}$.

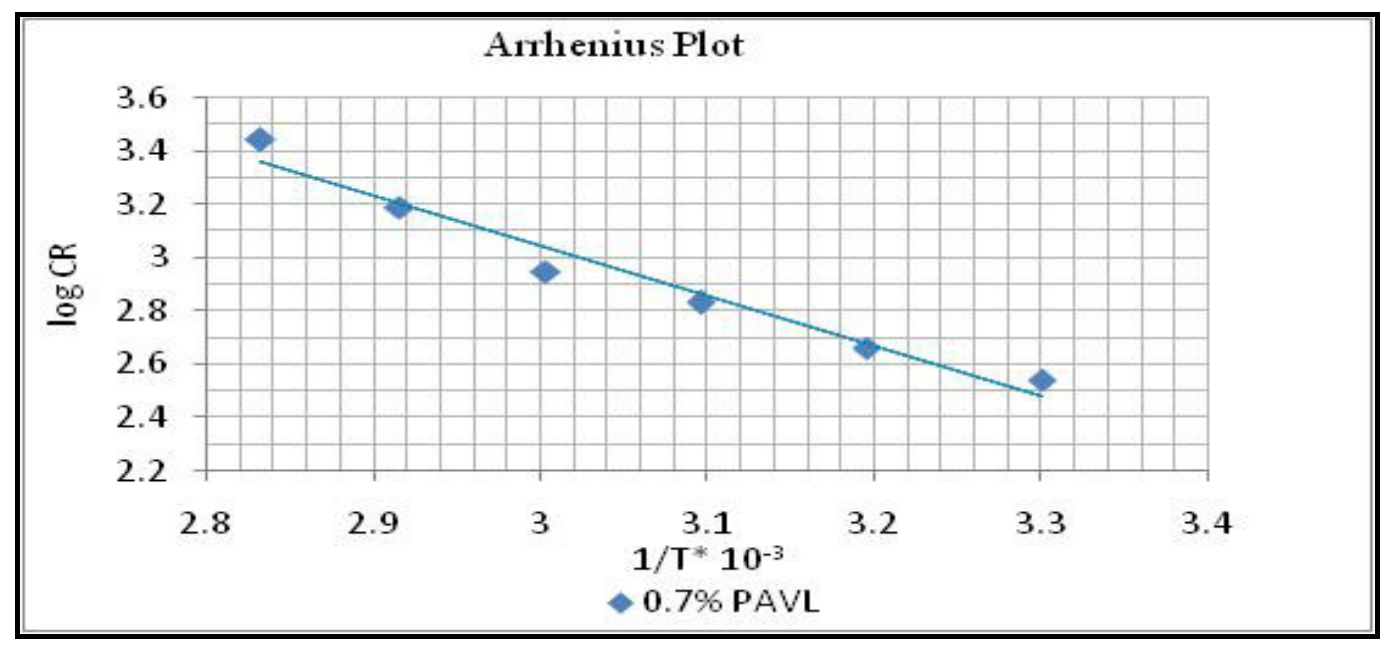

Fig.-3a: Arrhenius Plot for MS / PAVL /1M HCl

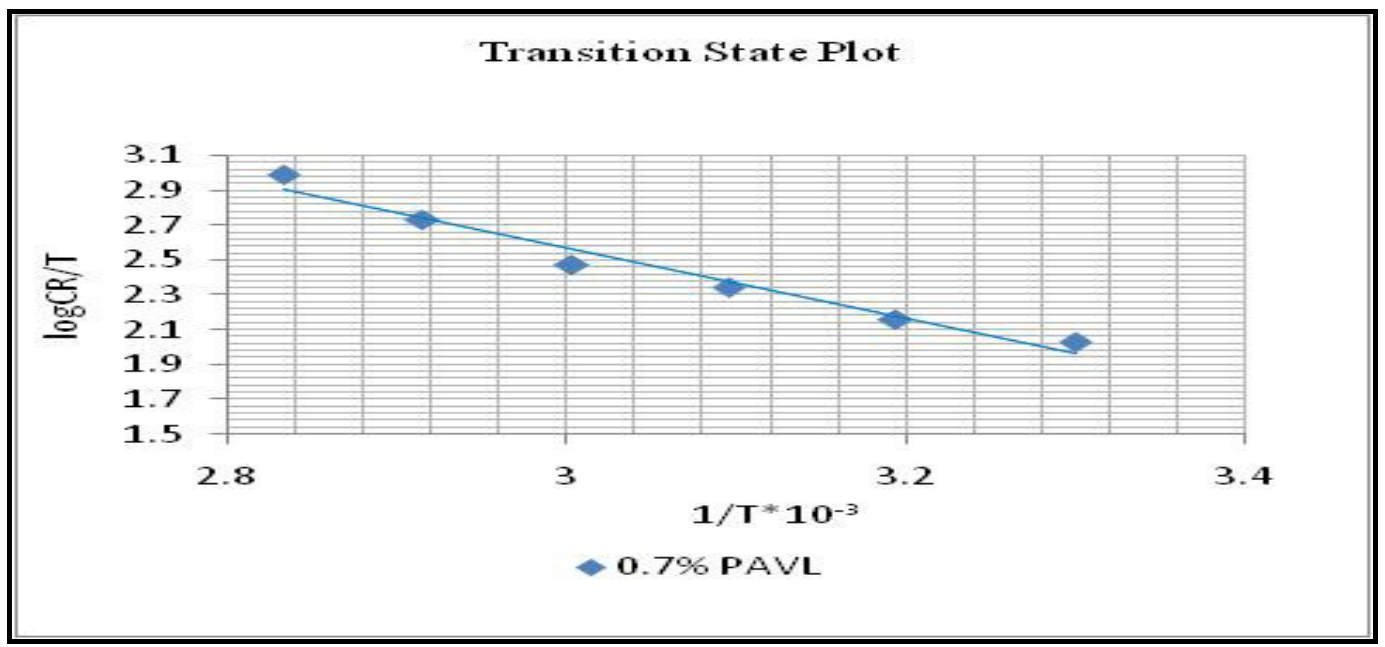

Fig.-3b: Transition State Plot for MS / PAVL /1M HCl

\section{Langmuir Adsorption Model for Investigated Inhibitor}

Langmuir adsorption equation relates to the degree of surface coverage to the concentration of inhibitor according to equation (2):

$\log (\mathrm{C} / \theta)=\log \mathrm{C}-\log \mathrm{K}$

A plot of $\log (\theta / 1-\theta)$ against $\log C$ from mass loss data obtained for investigated inhibitor yielded a straight line as represented in Fig.-4. The slope was found to deviate from unity and it was due to the interaction of the adsorbed molecules on the MS surface ${ }^{38}$. Hence in the current study, the PAVL molecule can be absorbed on the anodic and cathodic area and this may be the reason for deviation from the unit gradient. 


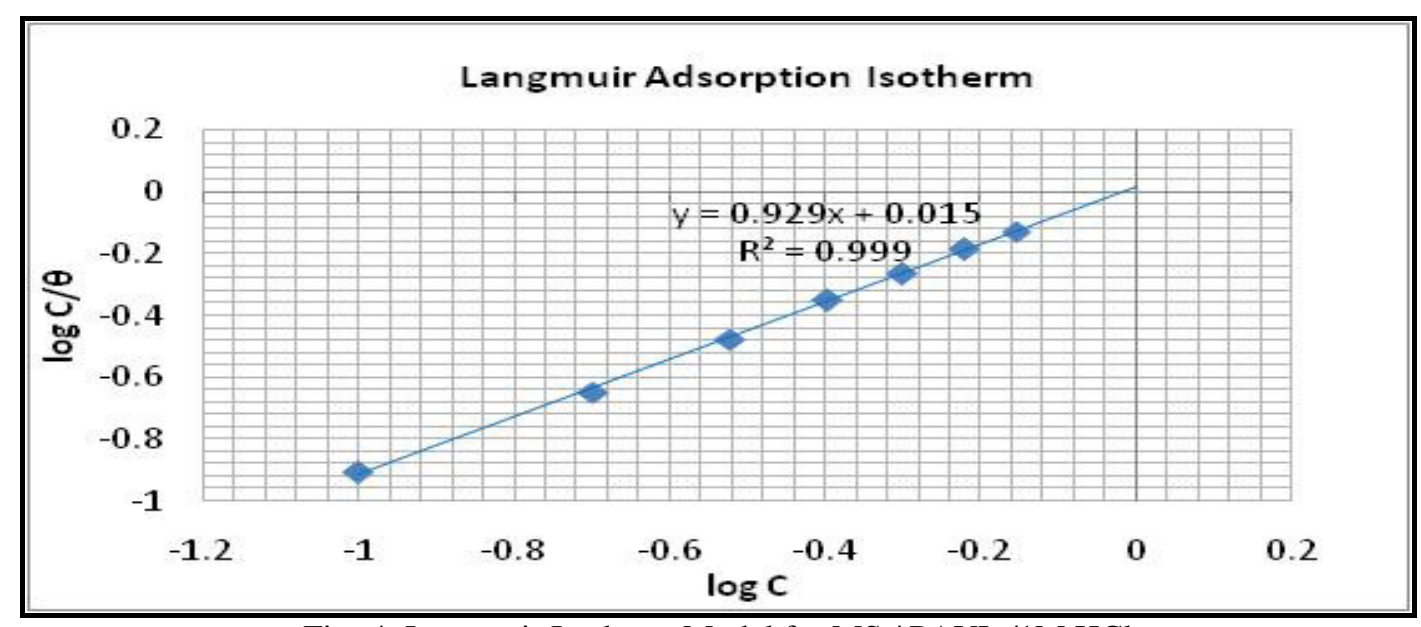

Fig.-4: Langmuir Isotherm Model for MS / PAVL /1M HCl

\section{The entropy of Activation and Enthalpy of Activation}

To calculate $\Delta \mathrm{H}_{\mathrm{a}}$ and $\Delta \mathrm{S}_{\mathrm{a}}$ for the corrosion process, the Arrhenius equation is used:

$\mathrm{CR} / \mathrm{T}=\mathrm{R} / \mathrm{Nh} \exp \left(\Delta \mathrm{S}_{\mathrm{a}} / \mathrm{R}\right) \exp (\Delta \mathrm{H} / \mathrm{RT})$

Where $\mathrm{h}$ is the Planck's constant, $\mathrm{N}$ is the Avogadro's number, $\Delta \mathrm{S}_{\mathrm{a}}$ is the entropy of activation, $\mathrm{T}$ is the absolute temperature and $\mathrm{R}$ is the universal gas constant. The relationship between $\log (\mathrm{CR} / \mathrm{T})$ against $1 / \mathrm{T}$ for MS acid corrosion in the absence and presence of PAVL extract is depicted in Figure $3 \mathrm{~b}$. Straight lines were obtained from the slope of $\left(-\Delta \mathrm{H}_{\mathrm{a}} / 2.303 \mathrm{R}\right)$ and an intercept of $\left(\log \mathrm{R} / \mathrm{Nh}+\Delta \mathrm{S}_{\mathrm{a}} / 2.303 \mathrm{R}\right)$. The values of $\Delta \mathrm{H}_{\mathrm{a}}$ and $\Delta \mathrm{S}_{\mathrm{a}}$ were obtained from the slope and intercept of a straight line. From Table-3 it may be noticed that the values of $\mathrm{E}_{\mathrm{a}}$ and $\Delta \mathrm{H}_{\mathrm{a}}$ were close to each other as expected from transition state theory and were also found to vary in a similar manner with PAVL extract but however, the value of $\Delta \mathrm{H}_{\mathrm{a}}$ was greater than that of $\mathrm{E}_{\mathrm{a}}$. The positive values of $\Delta \mathrm{H}_{\mathrm{a}}$ revealed that the reaction was endothermic nature of the steel dissolution process and this confirmed that the dissolution of MS was difficult ${ }^{39,40} . \Delta S_{a}$ values were negative and this indicated that the compounds present in PAVL extract absorbed orderly manner on the surface of the MS (Table-3).

Table-3: Activation Parameters for MS Corrosion in $1 \mathrm{M} \mathrm{HCl}$ in the Absence and Presence of PAVL

\begin{tabular}{c|c|c|c|c}
\hline $\begin{array}{c}\text { S. } \\
\text { No. }\end{array}$ & $\begin{array}{c}\text { Conc } \\
(\% \mathrm{v} / \mathrm{v})\end{array}$ & $E_{a}(\mathrm{KJ} / \mathrm{mol})$ & $\Delta H_{a}(\mathrm{KJ} / \mathrm{mol})$ & $\Delta S_{a}(\mathrm{~J} / \mathrm{mol})$ \\
\hline 1. & Blank & 33.6 & 36.3 & -18.1 \\
\hline 2. & 0.1 & 43.5 & 46.2 & -20.3 \\
\hline 3. & 0.2 & 38.4 & 41.1 & -20.5 \\
\hline 4. & 0.3 & 38.1 & 40.9 & -22.5 \\
\hline 5. & 0.4 & 38.9 & 41.6 & -21.2 \\
\hline 6 & 0.5 & 37.0 & 39.7 & -27.8 \\
\hline 7. & 0.6 & 37.2 & 40.0 & -27.7 \\
\hline 8. & 0.7 & 35.9 & 38.6 & -32.6 \\
\hline
\end{tabular}

\section{Thermodynamic Adsorption Parameters}

The adsorption behavior of PAVL extract on the MS surface is essential to control corrosion reaction. A plot of $\Delta \mathrm{G}^{\mathrm{o}}$ ads versus $\mathrm{T}$ (Figure 5) was linear for MS acid corrosion using PAVL extract in acidic medium. The slopes of the straight lines were equal to $\Delta \mathrm{S}^{\circ}$ ads and intercept equal to $\Delta \mathrm{H}^{\circ}$ ads. The calculated values of $\Delta \mathrm{G}_{\text {ads }}^{\mathrm{o}}, \Delta \mathrm{H}^{\mathrm{o}}$ ads, $\Delta \mathrm{S}_{\text {ads }}^{\mathrm{o}}$ at all investigated temperatures (303-353K) for different concentration of PAVL extract were listed in Table- 4 . The $\Delta \mathrm{G}^{\mathrm{o}}$ ads value was negative which indicated that the adsorption of the PAVL molecules on the MS surface was a spontaneous process. Generally, values of $\Delta \mathrm{G}^{\mathrm{o}}$ ads around -20 $\mathrm{kJmol}^{-1}$ or lower are consistent with the electrostatic interaction between the charged molecules and the 
charged metal (physisorption); those around $-40 \mathrm{kJmol}^{-1}$ or higher involve charge sharing or transfer from organic molecules to the metal surface to form a coordinate type of bond (chemisorption) ${ }^{41}$. In the current study, the obtained $\Delta \mathrm{G}_{\text {ads }}^{\mathrm{o}}$ values were slightly higher negative than $-20 \mathrm{kJmol}^{-1}$ ranging from -19 to -23 $\mathrm{kJmol}^{-1}$ which indicated that the adsorption process was physisorption. The obtained $\Delta \mathrm{H}^{\mathrm{o}}$ ads values were negative which identified that the adsorption of PAVL extract on metal surface was exothermic in nature ${ }^{42}$. The $\Delta \mathrm{S}_{\text {ads }}^{\mathrm{o}}$ values were negative which reflected that PAVL extract was absorbed well orderly manner on the surface of MS and resulting in a decrease in entropy values. Table 4 revealed that decreased in enthalpy and entropy were the driving force for the adsorption process ${ }^{43}$.

Table-4: Thermodynamic Parameters for MS Corrosion in $1 \mathrm{M} \mathrm{HCl}$ in the Absence and Presence of PAVL

\begin{tabular}{|c|c|c|c|c|c|c|c|c|}
\hline \multirow{2}{*}{$\begin{array}{l}\text { Conc } \\
(\% \mathrm{v} / \mathrm{v})\end{array}$} & \multicolumn{6}{|c|}{ Free energy of adsorption $-\Delta \mathrm{G}^{\mathrm{o}}$ ads $(\mathrm{KJ} / \mathrm{mol})$} & \multirow{2}{*}{$\begin{array}{l}\Delta \mathrm{S}_{\text {ads }}^{\mathrm{o}} \\
\mathrm{J} / \mathrm{mol}\end{array}$} & \multirow{2}{*}{$\begin{array}{l}\Delta \mathrm{H}^{\mathrm{o}} \text { ads } \\
\mathrm{KJ} / \mathrm{mol}\end{array}$} \\
\hline & $303 \mathrm{~K}$ & $313 \mathrm{~K}$ & $323 \mathrm{~K}$ & $333 \mathrm{~K}$ & $343 \mathrm{~K}$ & $353 \mathrm{~K}$ & & \\
\hline Blank & - & - & - & - & - & - & - & - \\
\hline 0.1 & 21.8 & 22.5 & 23.0 & 22.8 & 23.6 & 23.5 & -33.1 & -12.0 \\
\hline 0.2 & 20.5 & 21.2 & 21.8 & 22.7 & 22.8 & 22.8 & \begin{tabular}{|l|}
-49.1 \\
\end{tabular} & -5.8 \\
\hline 0.3 & 19.9 & 20.7 & 21.1 & 21.8 & 22.1 & 22.3 & -48.3 & -5.5 \\
\hline 0.4 & 19.5 & 20.4 & 20.7 & 21.1 & 21.8 & 21.7 & -44.6 & -6.2 \\
\hline 0.5 & 19.1 & 19.8 & 20.3 & 21.1 & 21.6 & 21.4 & $\begin{array}{l}-50.6 \\
\end{array}$ & -4.0 \\
\hline 0.6 & 18.7 & 19.7 & 20.2 & 20.7 & 21.3 & 21.1 & -49.4 & -4.1 \\
\hline 0.7 & 18.5 & 19.4 & 20.0 & 21.1 & 21.0 & 21.0 & $\begin{array}{l}-52.6 \\
\end{array}$ & -2.9 \\
\hline
\end{tabular}

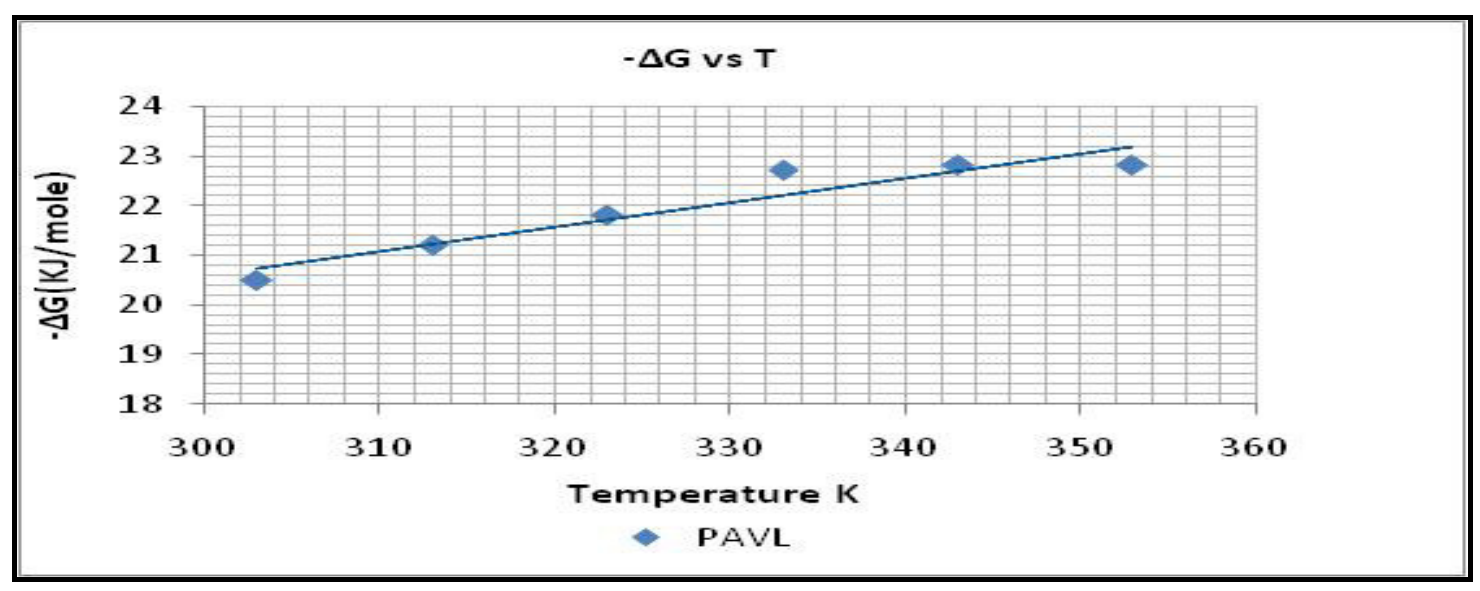

Fig.-5: Best fit curves of $-\Delta \mathrm{G}^{\circ}$ ads $V s \mathrm{~T}$ for MS / PAVL/ $1 \mathrm{M} \mathrm{HCl}$

\section{Electrochemical Measurements}

\section{Potentiodynamic Polarisation Technique}

Electrochemical studies were used to predict the nature of the inhibitor and to determine the suitable mechanism for the inhibition process. The potentiodynamic polarisation curves reflected a slight change in the anodic $\left(b_{a}\right)$ and cathodic $\left(b_{c}\right)$ curves with and without the addition of PAVL extract (Fig. 6 and Table-5). This indicated that the inhibitor was able to suppress both the anodic dissolution and cathodic hydrogen evolution. The results revealed that $\mathrm{I}_{\text {corr }}$ values decreased with increase in the concentration of PAVL extract. Inspection of the values showed that $I_{\text {corr }}$ values decreased from $212 \mathrm{~A} / \mathrm{cm}^{2}$ to $22 \mathrm{~A} / \mathrm{cm}^{2}$. This indicated the inhibitor was able to minimize corrosion of MS in the investigated acid medium ${ }^{44}$. A maximum of 89.8 percentage of inhibition was obtained at $0.7 \%$ concentration of PAVL extract. No significant shifts in the $\mathrm{E}_{\text {corr }}$ values were noticed in the presence of the inhibitor. In general, an inhibitor is differentiated as cathodic and anodic inhibitor if the shift is more than $85 \mathrm{mV}$ with respect to that of the blank. In the current study, the $\mathrm{E}_{\text {corr }}$ values were lower than $85 \mathrm{mV}$ than the blank value, indicating the mixed nature of the inhibitor ${ }^{45} . \mathrm{R}_{\mathrm{p}}$ values were found to vary from $1590 \mathrm{hm} / \mathrm{cm}^{2}$ for the uninhibited solution to $710 \mathrm{Ohm} / \mathrm{cm}^{2}$ for the optimum concentration of the inhibitor (0.7\% PAVL). The inhibitor 
RASĀYAN J. Chem.

Vol. 12 | No. 2 |431 - 449| April - June | 2019

afforded an efficiency of 77.6 percentage. This might be due to the adsorption of active compounds present in PAVL extract onto the metal surface ${ }^{46}$.

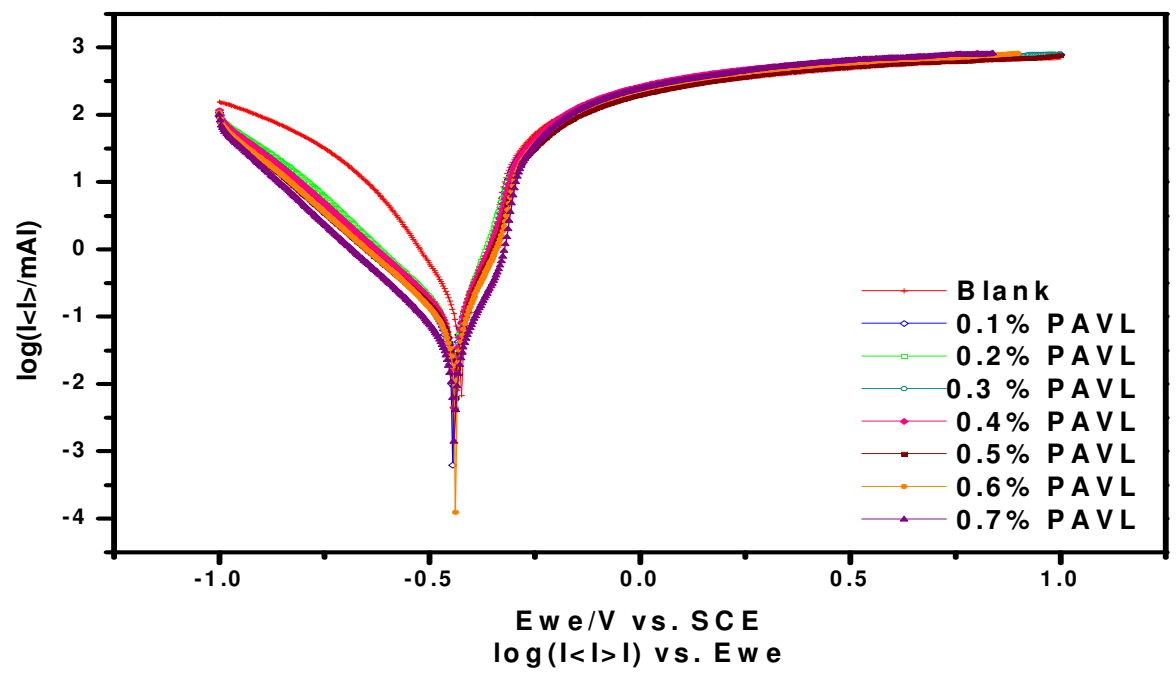

Fig.-6: Polarization Plot for MS / PAVL/1M HCl

Table-5: Electrochemical Polarization Parameters for MS in 1M HCl in the Absence and Presence of Various

\begin{tabular}{c|c|c|c|c|c|c|c|c}
\hline $\begin{array}{c}\text { S. } \\
\text { No. }\end{array}$ & $\begin{array}{c}\text { Conc } \\
(\% \mathrm{v} / \mathrm{v})\end{array}$ & $\begin{array}{c}\mathrm{E}_{\mathrm{corr}} \\
\left(\mathrm{Amp} / \mathrm{cm}^{2}\right)\end{array}$ & $\begin{array}{c}\mathrm{b}_{\mathrm{a}} \\
(\mathrm{mv} / \mathrm{dec})\end{array}$ & $\begin{array}{c}\mathrm{b}_{\mathrm{c}} \\
(\mathrm{mv} / \mathrm{dec})\end{array}$ & $\begin{array}{c}\mathrm{I}_{\mathrm{corr}} \\
\left(\mathrm{Amp} / \mathrm{cm}^{2}\right)\end{array}$ & $\begin{array}{c}\mathrm{IE} \\
\%\end{array}$ & $\begin{array}{c}\mathrm{R}_{\mathrm{p}} \\
\Omega / \mathrm{cm}^{2}\end{array}$ & $\begin{array}{c}\mathrm{IE} \\
(\%)\end{array}$ \\
\hline 1 & Blank & -444 & 78.8 & 115.9 & 212 & - & 159 & - \\
\hline 2 & 0.1 & -438 & 61.1 & 160.0 & 101 & 52.4 & 267 & 40.4 \\
\hline 3 & 0.2 & -447 & 70.8 & 171.4 & 79 & 62.7 & 276 & 42.4 \\
\hline 4 & 0.3 & -434 & 61.9 & 172.5 & 70 & 67.0 & 329 & 51.7 \\
\hline 5 & 0.4 & -430 & 61.5 & 178.7 & 64 & 69.8 & 335 & 52.5 \\
\hline 6 & 0.5 & -426 & 60.9 & 184.1 & 61 & 71.2 & 350 & 54.6 \\
\hline 7 & 0.6 & -418 & 55.4 & 174.8 & 49 & 77.0 & 379 & 58.0 \\
\hline 8 & 0.7 & -401 & 43.7 & 167.6 & 22 & 89.8 & 710 & 77.6 \\
\hline
\end{tabular}

\section{Electrochemical Impedance Measurements}

The impedance parameters for MS/1M HCl/PAVL obtained from Nyquist plots (Fig.-7) were collected in Table-6. The observed impedance spectra exhibited a single depressed semicircle whose diameter increased with increase in the concentration of the inhibitor implying a charge transfer process for the corrosion inhibition process $^{47}$. From Fig.-7, it can be noticed that the presence of the inhibitor did not modify the corrosion reaction of MS electrode. The impedance parameters suggested an increase in charge transfer resistance $\left(R_{\mathrm{ct}}\right)$ values with increase in the concentration of the inhibitor. A maximum of 86.3 percentage IE was obtained at $0.7 \%$ PAVL. Single capacitive semicircle in Nyquist plot corresponded to a single time constant in the Bode representation ${ }^{48}$. A decrease in $C_{\mathrm{dl}}$ values were noticed with increase in PAVL extract concentration. This might be due to an increase in surface coverage which increased the IE by the PAVL molecules of plant extract ${ }^{49}$.

The nyquist plot was analyzed by a simple circuit model depicted in Fig.-8 which included solution resistance $\left(R_{\mathrm{s}}\right)$, charge transfer element $\left(\mathrm{R}_{\mathrm{ct}}\right)$, constant phase element $(\mathrm{CPE})$ and surface inhomogeneity (n) and the values are tabulated (Table-6). Non-linear least square fit of equivalent circuit model as shown in Figure-8 was employed for extracting impedance values from the Nyquist plot. 
RASĀYAN J. Chem.

Vol. 12 | No. 2 |431 - 449| April - June | 2019

Table-6: Impedance Values of Mild Steel Acid Corrosion with and without Addition of PAVL in 1M HCl

\begin{tabular}{c|c|c|c|c|c|c|c}
\hline $\begin{array}{c}\text { Conc } \\
(\% \mathrm{v} / \mathrm{v})\end{array}$ & $\begin{array}{c}\mathrm{R}_{\mathrm{s}} \\
\left(\Omega \mathrm{cm}^{2}\right)\end{array}$ & $\begin{array}{c}\mathrm{Y}_{\mathrm{o}} \\
\left(\mu \mathrm{F} / \mathrm{cm}^{2}\right)\end{array}$ & $\mathrm{n}$ & $\begin{array}{c}\mathrm{R}_{\mathrm{ct}} \\
\left(\Omega \mathrm{cm}^{2}\right)\end{array}$ & $\begin{array}{c}\mathrm{IE} \\
(\%)\end{array}$ & $\begin{array}{c}\mathrm{CPE} / \mathrm{C}_{\mathrm{dl}} \\
\left(\mu \mathrm{F} / \mathrm{cm}^{2}\right) \\
\mathrm{x} 10^{-6}\end{array}$ & $\theta$ \\
\hline Blank & 2.09 & 8071 & 0.84 & 19.7 & - & 89.4 & - \\
\hline 0.1 & 2.81 & 5763 & 0.86 & 27.6 & 28.6 & 62.7 & 0.30 \\
\hline 0.2 & 3.18 & 4865 & 0.84 & 32.7 & 39.7 & 50.0 & 0.44 \\
\hline 0.3 & 2.92 & 4177 & 0.90 & 38.1 & 48.2 & 60.7 & 0.32 \\
\hline 0.4 & 2.85 & 3778 & 0.91 & 42.2 & 53.2 & 63.4 & 0.29 \\
\hline 0.5 & 3.10 & 2059 & 0.95 & 77.3 & 74.5 & 54.3 & 0.39 \\
\hline 0.6 & 3.05 & 1369 & 0.98 & 116.3 & 83.0 & 58.8 & 0.34 \\
\hline 0.7 & 3.64 & 1103 & 0.98 & 144.4 & 86.3 & 44.1 & 0.51 \\
\hline
\end{tabular}
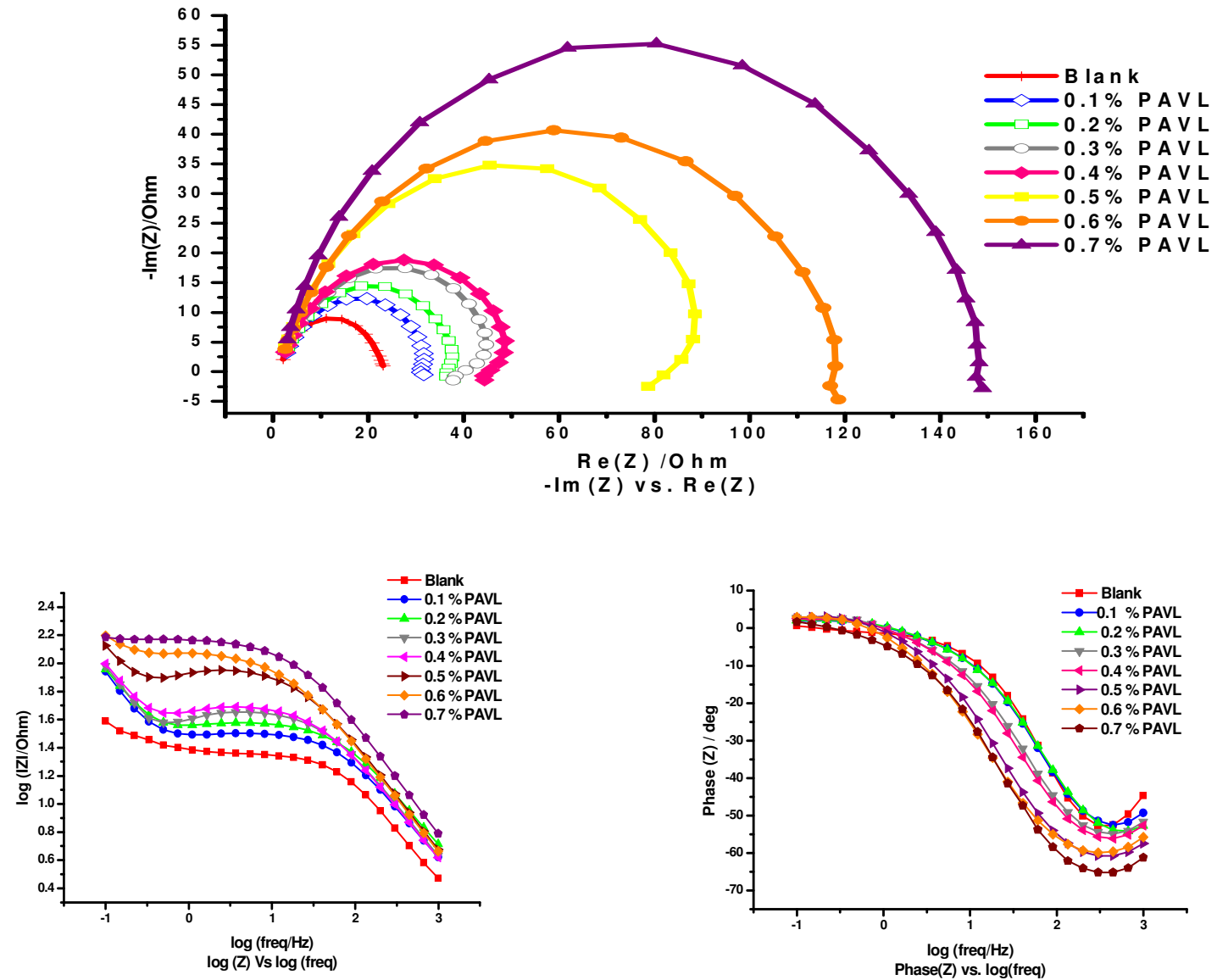

Fig.-7: Nyquist and Bode Plots for MS/PAVL/1M HCl

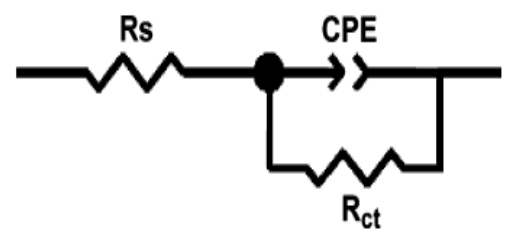

Fig.-8: Equivalent Circuit Model 
The double layer capacitance $\left(\mathrm{C}_{\mathrm{dl}}\right)$ decreased due to increase in double layer thickness via adsorption of PAVL molecules on MS surface ${ }^{50}$. The $\mathrm{C}_{\mathrm{dl}}$ values were obtained from equation (4):

$\mathrm{C}_{\mathrm{dl}}=\mathrm{Y}_{0}\left(\omega_{\max }\right)^{\mathrm{n}-1}$

Where, $\mathrm{Y}_{0}$ is CPE coefficient, $\mathrm{n}$ is CPE exponent , $\omega$ is the angular frequency.

The thickness of the protective layer (d) is associated with $\mathrm{C}_{\mathrm{dl}}$ by the equation (5)

$\mathrm{C}_{\mathrm{dl}}=\varepsilon \varepsilon_{\mathrm{o}} \mathrm{A} / \mathrm{d}$

Where, $\varepsilon$ is the dielectric constant and $\varepsilon_{0}$ is the permittivity of the free space and $A$ is surface area of the metal.

When the inhibitor concentration was increased to $0.7 \%$ in the corrosive medium, the interface $(\tau)$ parameter changes while the capacitance $\left(\mathrm{C}_{\mathrm{dl}}\right)$ value decreased signifying that the charge and discharge rates to the metal-solution interface was greatly decreased. This showed that there was an agreement between the amounts of charge that can be stored (i.e. capacitance) and the discharge velocity in the interface $(\tau)$. The double layer between the charged MS surface and the solution was considered as an electrical capacitor. The adsorption of PAVL molecules on the MS surface reduced its electrical capacity because they displaced the water molecules and other ions adsorbed on the metal surface. The results of the electrochemical studies were in good agreement with the results of gravimetric studies with slight deviations. This was due to the difference in immersion period of MS in the aggressive media ${ }^{51}$.

\section{Surface Analysis \\ UV Spectral Analysis}

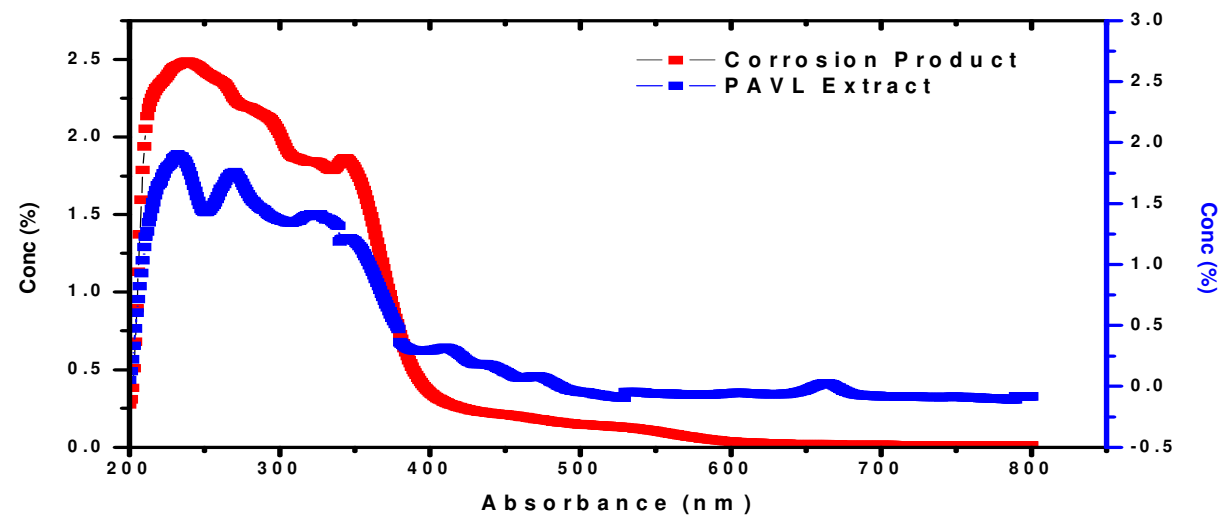

Fig.-9: UV-Visible Spectrum of Crude PAVL and Corrosion Product

Table-7: UV Visible Spectral Values of PAVL Extract and Corrosion Product

\begin{tabular}{c|c|c}
\hline \multirow{2}{*}{ Inhibitor } & \multicolumn{2}{|c}{ Absorption Band (nm) } \\
\cline { 2 - 3 } & Crude PAVL Extract & Corrosion Product \\
\hline \multirow{2}{*}{ PAVL extract } & $270,250,232,200,322,308$ & $238,242,375,397$ \\
\hline
\end{tabular}

A UV-visible spectrum is used to analyze the formation of the Fe-PAVL complex and it was recorded for $0.7 \%$ of PAVL extract in $1 \mathrm{M} \mathrm{HCl}$ solution before and after immersion of MS for 3h. (Fig.-9). The absorption spectra of PAVL in $1 \mathrm{M} \mathrm{HCl}$ before immersion of MS reflected two bands in the UV region. These bands were obtained due to $n \rightarrow \pi^{*}$ and $\pi \rightarrow \pi^{*}$ transitions. The change in the position of the absorption maximum was indicated the formation of a complex between the phytochemical constituents of the plant extract and MS electrode ${ }^{52,53}$. 


\section{FT-IR Analysis}

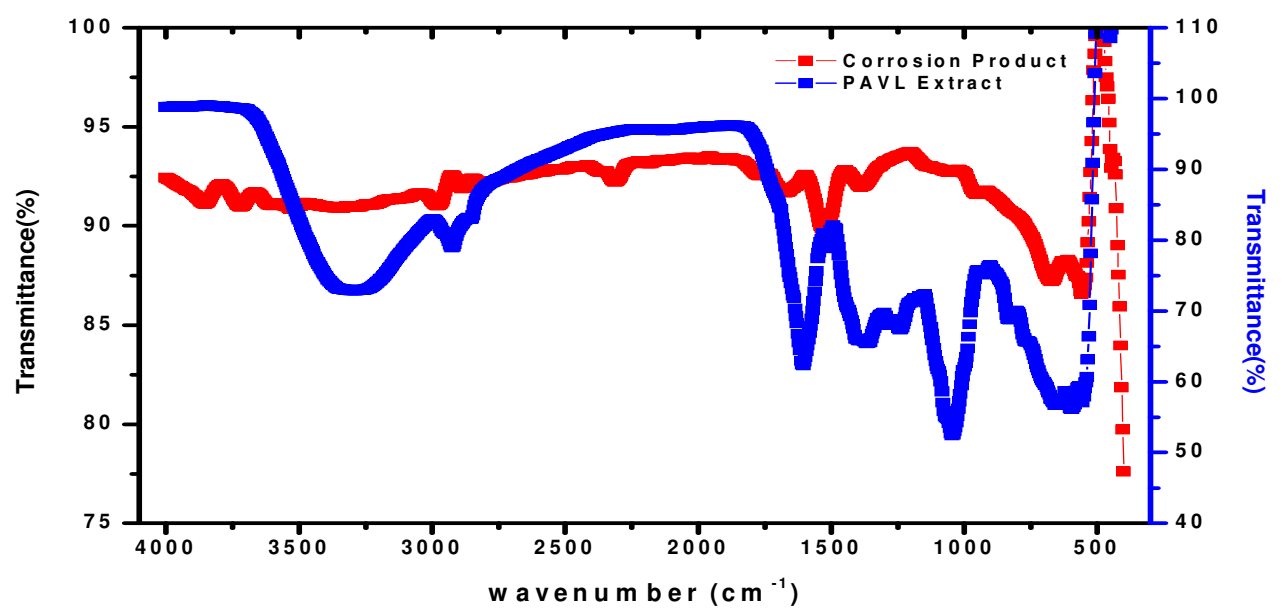

Fig.-10: FT-IR Spectrum of PAVL Crude Plant Extract and Corrosion Product

Table-8: FT-IR Spectral Values of PAVL Crude Plant Extract and Corrosion Product of MS in Acidic Medium Observed IR Frequency $\left(\mathrm{cm}^{-1}\right)$ and Peak Assignment

\begin{tabular}{c|c|c}
\hline Crude Plant Extract & $\begin{array}{c}\text { Corrosion Product/Mild } \\
\text { Steel/1M HCl }\end{array}$ & Frequency Assignment \\
\hline 3977 & 3981 & O-H stretching \\
\hline 3318 & 3603 & N-H/O-H stretching \\
\hline 2924 & 3116 & $\mathrm{C}-\mathrm{H}$ stretching \\
\hline 2300 & 2314 & $-\mathrm{C} \equiv \mathrm{N}$ stretching \\
\hline 1605 & 1635 & $\mathrm{C}=\mathrm{C}$ stretching \\
\hline 1512 & 1519 & $\mathrm{C}-\mathrm{C}$ in ring aromatic \\
\hline 1366 & 1381 & $\mathrm{C}-\mathrm{O}-\mathrm{C}$ stretching \\
\hline 1045 & 1072 & $\mathrm{C}-\mathrm{O}$ stretching \\
\hline 633 & - & $\mathrm{C}=\mathrm{C}$ bending \\
\hline
\end{tabular}

Figure.10 depicted the IR spectrum of the PAVL extract and corrosion product. Various adsorption modes of the PAVL extract and the protective film formed on the metal surface after immersion in an acidic solution containing $0.7 \%$ PAVL extract and their corresponding frequencies were tabulated and analyzed (Table 8). Analysis of the IR spectral data reflected the following points: The band at $3977 \mathrm{~cm}^{-1}$ shifted to $3981 \mathrm{~cm}^{-1}$ in the corrosion product. The adsorption bands at $2314 \mathrm{~cm}^{-1}$ and $1635 \mathrm{~cm}^{-1}$ pertaining to $\mathrm{C} \equiv \mathrm{N}$ stretching and $\mathrm{C}=\mathrm{C}$ stretching were noticed for the corrosion product. Also, a shift from $2924 \mathrm{~cm}^{-1}$ to $3116 \mathrm{~cm}^{-1}$ was noted for C-H bending. A shift from $1366 \mathrm{~cm}^{-1}$ to $1381 \mathrm{~cm}^{-1}$ indicated C-O-C stretch. Some bands, for example, $633 \mathrm{~cm}^{-1}$ corresponding to $\mathrm{C}=\mathrm{C}$ bending vibration for the aromatic ring system disappeared in the corrosion product. A peak shift from $1045 \mathrm{~cm}^{-1}$ to $1072 \mathrm{~cm}^{-1}$ indicated C-O stretching. The interaction of the phytochemical compounds of PAVL extract with MS surface can be identified by the shift in the adsorption frequency of the inhibitor on MS surface ${ }^{54}$.

\section{D Optical Profilometry}

The three-dimensional optical profiler images of the MS surface with and without the addition of PAVL in $1 \mathrm{M} \mathrm{HCl}$ are depicted in Fig.-11 a, b and c respectively. Surface morphology of MS showed cracks or depth on the MS surface which was due to the attack of acid on it (Fig.-11b). After the addition of optimum concentration of PAVL, (Fig.-11c) the cracks on the surface of the metal were covered homogeneously. Further, the MS surface was found to be smoother by the addition of the inhibitor 
solution. Furthermore, the average roughness on MS sample reduced from $17.28 \mu \mathrm{m}$ for MS without inhibitor to 7.65 $\mu \mathrm{m}$ for MS with optimum concentration of PAVL. The decrease in $\mathrm{R}_{\mathrm{a}}$ value indicated the adsorption of PAVL molecules on the MS surface (Table-9).

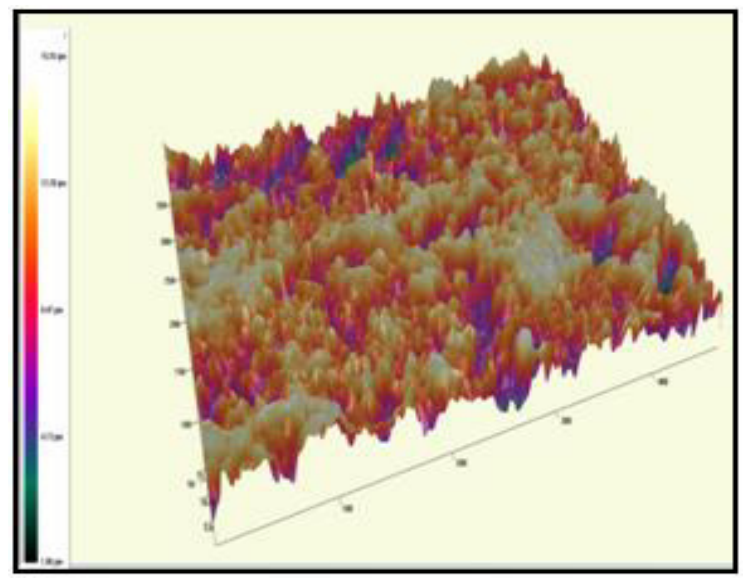

(a) Plain MS

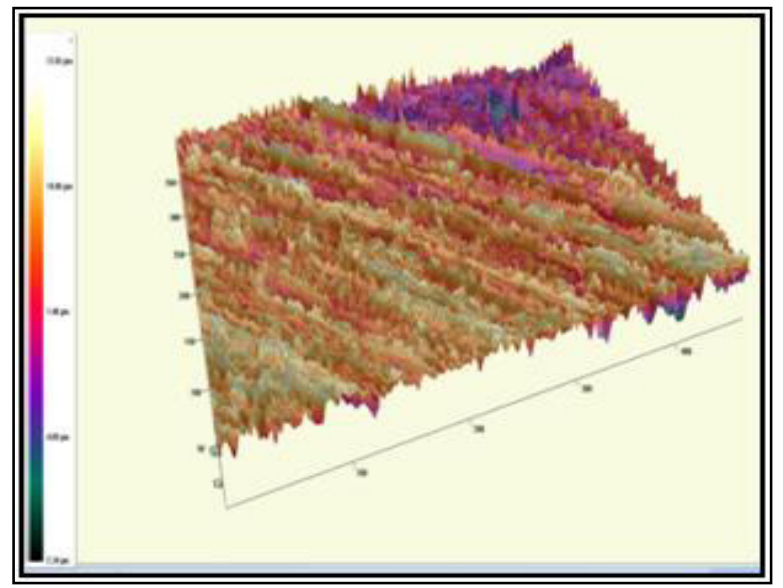

(b) $\mathrm{MS} / 1 \mathrm{M} \mathrm{HCl}$

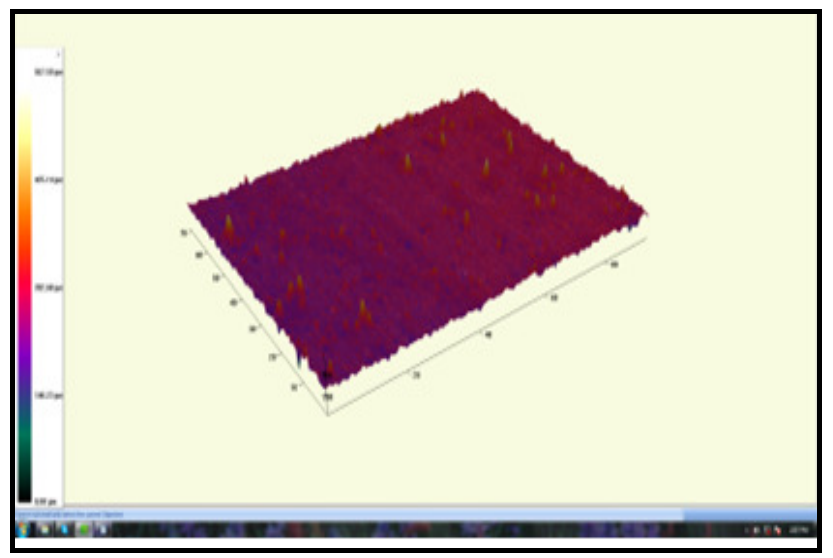

(c) MS/PAVL/1M HCl

Fig.-11: 3D Optical Profiler Images for MS/ PAVL / 1M HCl

Table-9: $\mathrm{R}_{\mathrm{a}}$ and $\mathrm{R}_{\mathrm{q}}$ Values for MS/PAVL/1M HCl

\begin{tabular}{c|c|c|c}
\hline S. No. & Samples & $\begin{array}{c}\text { Average Roughness } \\
\text { Values, } \mathrm{R}_{\mathrm{a}}(\mu \mathrm{m})\end{array}$ & $\begin{array}{c}\text { Root Mean Square Roughness } \\
\mathrm{R}_{\mathrm{q}}(\mu \mathrm{m})\end{array}$ \\
\hline 1. & Plain MS & 2.558 & 3.140 \\
\hline 2. & MS in 1M HCl & 17.28 & 22.35 \\
\hline 3. & $\begin{array}{c}\text { MS in 1M HCl + 0.7\% } \\
\text { PAVL Extract }\end{array}$ & 7.65 & 10.16 \\
\hline
\end{tabular}

\section{SEM Analysis}

Surface morphology of the MS sample before immersion in the test solution and of the MS sample in 1M $\mathrm{HCl}$ with and without the addition of PAVL extract after $3 \mathrm{~h}$ immersion time was recorded and presented in Fig.-12a to 12c. The MS surface immersed in an acid medium in the absence of the extract (Fig.-12b) showed defined corrosion pits reflecting a high degree of localized corrosion attack by the acid medium. The observed corrosion pit was absent in the MS surface in which the PAVL extract was present in the acid solution (Fig.-12c). The surface morphology of the samples immersed in an acidic solution containing the extract (Fig.-12c) was observed to be very much alike in topography to that of the MS before immersion in the acidic solution (Fig.-12b). This suggested the formation of a protective layer 
formed by the extract on the mild steel that tends to serve as a barrier limiting the extent of corrosion attack by the acid solution ${ }^{55}$.

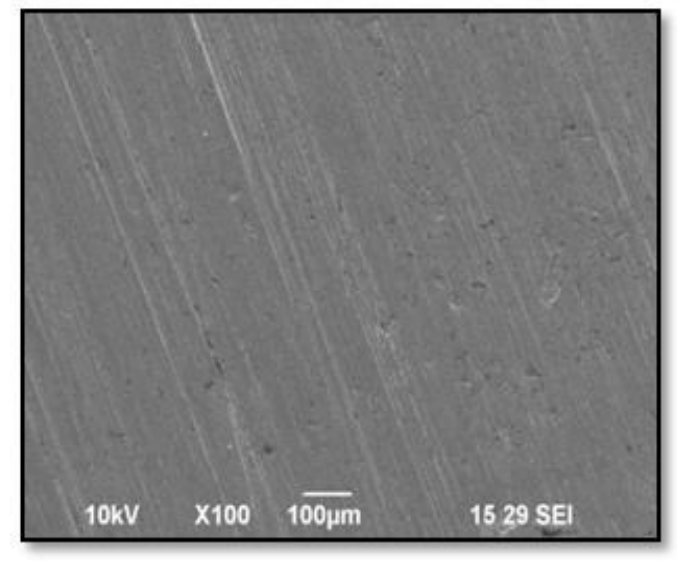

(a) Plain MS

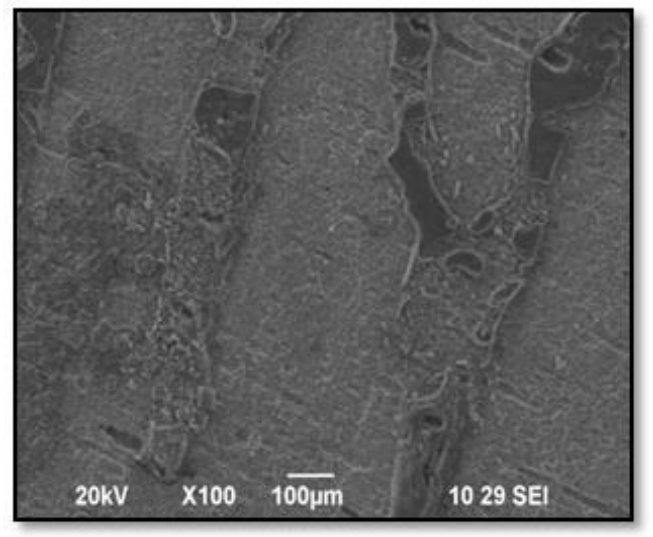

(b) $\mathrm{MS} / 1 \mathrm{M} \mathrm{HCl}$

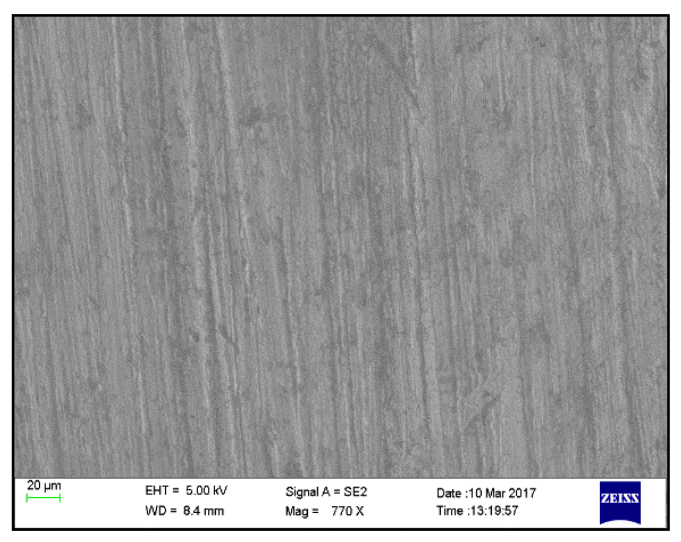

(c) $\mathrm{MS} / \mathrm{PAVL} / 1 \mathrm{M} \mathrm{HCl}$

\section{EDX Analysis}

Fig.-12: SEM Pictures of MS/ PAVL/ 1M HCl

The chemical composition of the surface of the MS sample with and without the addition of PAVL extract in 1M HCl solution was analyzed by EDX. The EDX spectra are shown in Figures-13a to 13c. The EDX spectra of inhibited samples showed suppressed Fe peaks, when compared with the polished and uninhibited mild steel sample. This suppression of Fe lines was due to the protective film formed on the MS surface. The EDX spectra of inhibited MS sample contained the peaks corresponding to all the elements present in the inhibitor molecules indicating adsorption of PAVL molecules on metal surface ${ }^{56}$.

\section{Mechanism}

The adsorption of the inhibitor depends on the factors like the chemical composition of the inhibitor, the temperature and electrochemical potential on the metal/solution interface. In fact, the solvent water molecules could also adsorb at a metal/ solution interface. Adsorption process can occur through the replacement of solvent molecules from metal surfaces by ions and molecules accumulated near the metal/solution interface. The anions get adsorbed when the metal surface has an excess positive charge in an amount greater than that required to balance the charge corresponding to the applied potential.

The phytochemicals present in the PAVL extract are listed in Table 10. The results indicated that the presence of phytoconstituents like steroids, flavonoids, alkaloids, terpenoids, saponins, phenols, glycosides, cholesterol and polyphenols in the leaves and a moderate amount of flavonoids, terpenoids and anthraquinones in the flowers extract. These were corroborated by literature survey ${ }^{57}$. 
RASĀYAN J. Chem.

Vol. 12 | No. 2 |431 - 449| April - June | 2019

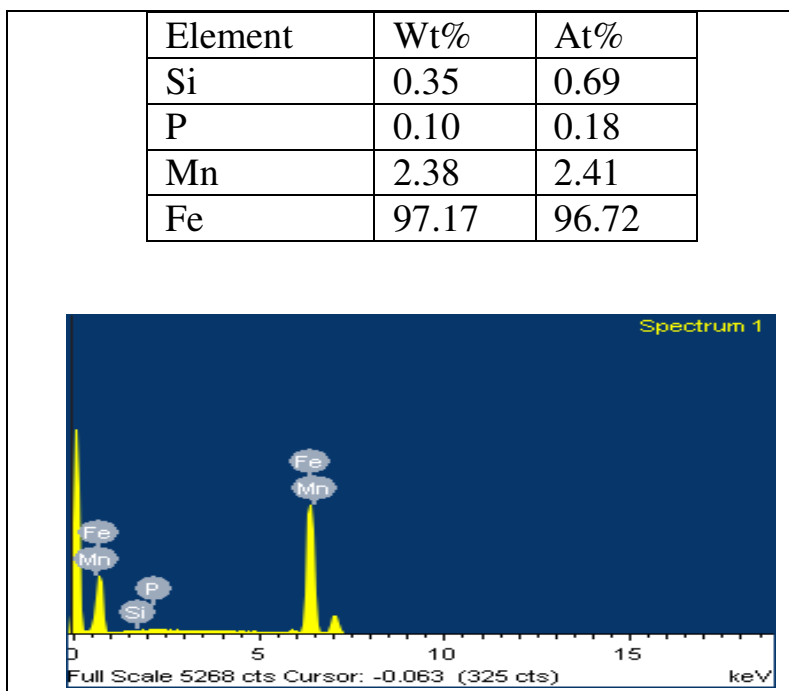

(a) Plain MS

\begin{tabular}{|c|l|l|}
\hline Element & $\mathrm{Wt} \%$ & At \% \\
\hline $\mathrm{O}$ & 19.79 & 45.36 \\
\hline $\mathrm{Fe}$ & 79.00 & 53.41 \\
\hline $\mathrm{C}$ & 0.73 & 1.23 \\
\hline $\mathrm{Si}$ & 0.48 & 0.73 \\
\hline
\end{tabular}

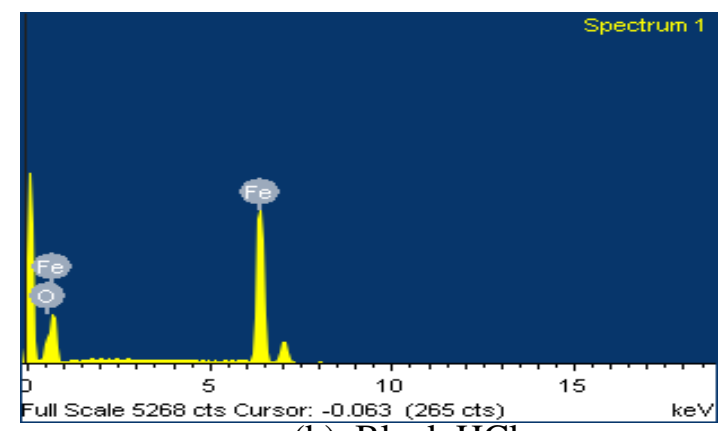

(b) Blank $\mathrm{HCl}$

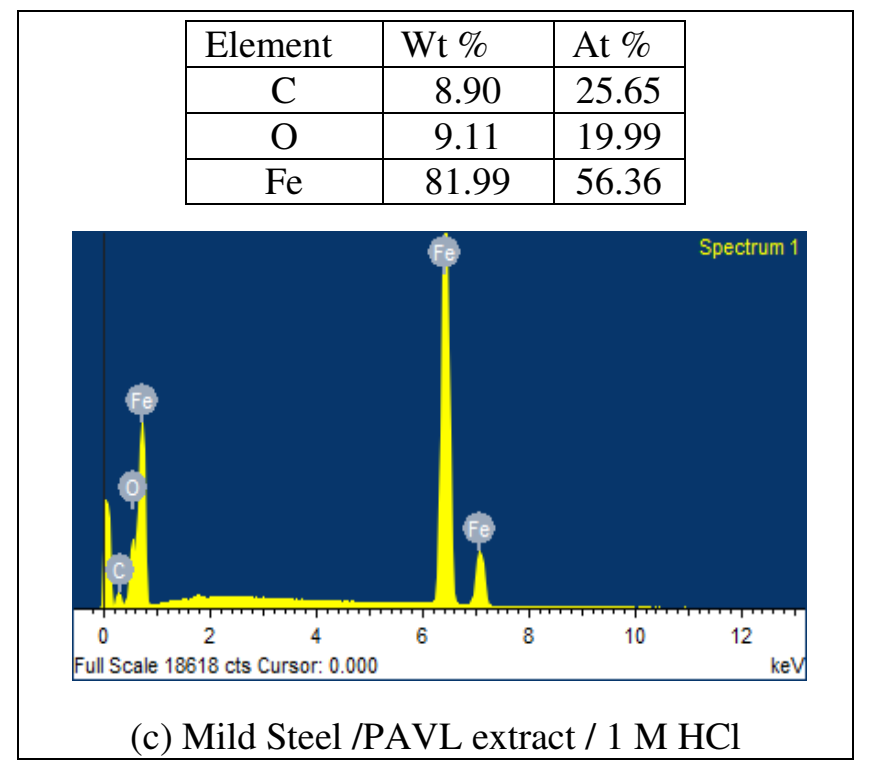

Fig.-13: EDX images of MS/PAVL/1M HCl

Table-10: Preliminary Phytochemical Screening of the Crude Extract

\begin{tabular}{c|l|c}
\hline S.No. & \multicolumn{1}{|c|}{ PAVL Extract } & Phytochemical Constituents \\
\hline 1. & Carbohydrates & - \\
\hline 2. & Steroids & + \\
\hline 3. & Flavonoids & + \\
\hline 4. & Alkaloids & + \\
\hline 5. & Terpenoids & + \\
\hline 6. & Saponins & + \\
\hline 7. & Phenols & + \\
\hline 8. & Glycosides & - \\
\hline 9. & Cholesterol & + \\
\hline 10. & Proteins & - \\
\hline 11. & Polyphenols & \\
\hline 12. & Anthraquinones & + \\
\hline
\end{tabular}

$(+)=$ indicate presence; $(-)=$ indicate absence 


\section{UV-vis Spectrophotometer}

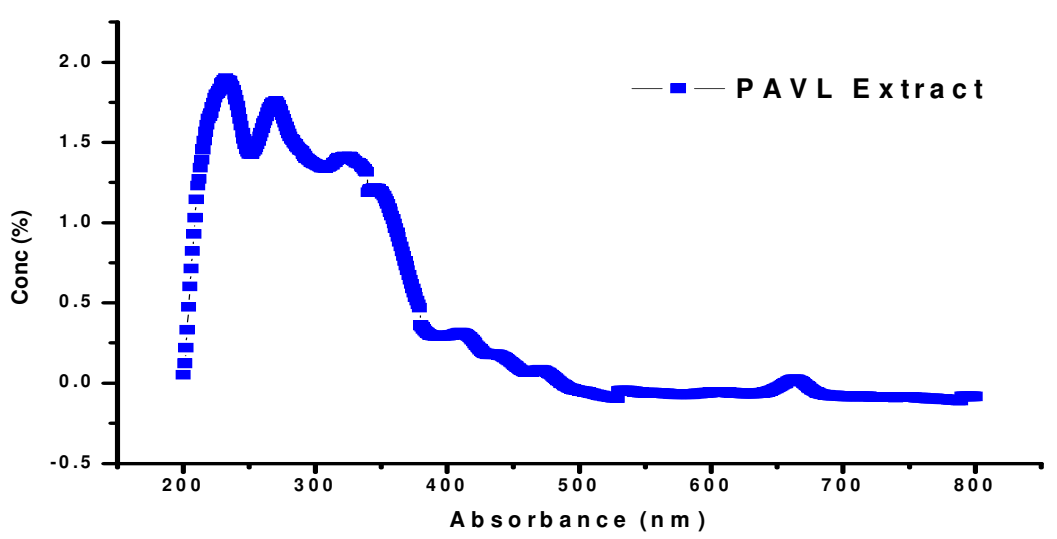

Fig.-14: UV Visible Spectral Details of PAVL Crude Plant Extract

Table-11: UV Visible Spectral Details of PAVL Crude Plant Extract

\begin{tabular}{c|c}
\hline Inhibitor & Absorption band (nm) \\
\hline PAVL & $270,250,232,200,322,308$ \\
\hline
\end{tabular}

The UV-visible spectrum of PAVL crude extract is shown in Fig.-14 and their corresponding values were listed in Table-11. UV-visible spectroscopy is an essential technique to analyze the nature of phytochemical constituents present in the leaves extract. The results revealed that the major peak appeared at $232 \mathrm{~nm}$ and $250 \mathrm{~nm}$. Evidently, a peak at $232 \mathrm{~nm}$ was obtained by the electron transition of $\mathrm{n}$ $\rightarrow \sigma^{*}$ in $\mathrm{N}$ and $\mathrm{O}$ atoms. The result inferred that the most important constitution compounds in PAVL extract were flavonoids, alkaloid and other compounds containing $\mathrm{N}$ or $\mathrm{O}$ atoms ${ }^{58}$.

\section{FT-IR Analysis}

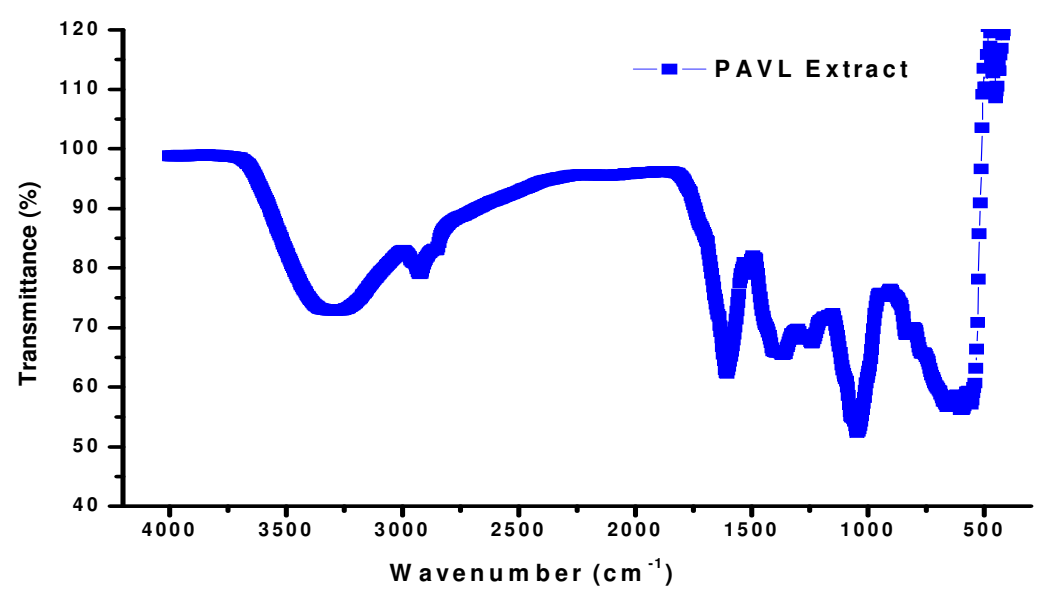

Fig.-15: FT-IR Spectra Values for PAVL Crude Plant Extract

The FTIR spectrum of PAVL is depicted in Fig.-15 and the observed frequencies are tabulated (Table12). A strong band at $3318 \mathrm{~cm}^{-1}$ was attributed to $\mathrm{N}-\mathrm{H} / \mathrm{OH}$ stretching. An absorption band related to $-\mathrm{CH}_{2}$ stretching was noticed at $2924 \mathrm{~cm}^{-1}$. The strong band at $1605 \mathrm{~cm}^{-1}$ corresponds to $\mathrm{C}=\mathrm{C}$ stretching. Peaks at $1512 \mathrm{~cm}^{-1}, 1045 \mathrm{~cm}^{-1}$ indicated $\mathrm{C}=\mathrm{C}$ stretching and $\mathrm{C}-\mathrm{O}$ aromatic system. The peak at $633 \mathrm{~cm}^{-1}$ denoted $\mathrm{C}=\mathrm{C}$ bending vibration of the aromatic ring system. FTIR spectral values revealed that PAVL extract contained the functional groups such as $\mathrm{C}-\mathrm{N}, \mathrm{C}-\mathrm{O}, \mathrm{O}-\mathrm{H}, \mathrm{N}-\mathrm{H}, \mathrm{C}=\mathrm{N}$ linkages and aromatic rings. 
Vol. 12 | No. 2 |431 - 449| April - June | 2019

Table-12: FT-IR Spectral Details of PAVL Crude Plant Extract

Observed IR Frequency $\left(\mathrm{cm}^{-1}\right)$ and Peak Assignment

\begin{tabular}{c|c}
\hline Crude Plant Extract & Frequency Assignment \\
\hline 3977 & O-H stretching \\
\hline 3318 & N-H/O-H stretching \\
\hline 2924 & C-H stretching \\
\hline 2300 & $-\mathrm{C} \equiv$ N stretching \\
\hline 1605 & $\mathrm{C}=\mathrm{C}$ stretching \\
\hline 1512 & C-C aromatic ring \\
\hline 1366 & C-O-C stretching \\
\hline 1045 & C-O stretching \\
\hline 633 & $\mathrm{C}=\mathrm{C}$ bending \\
\hline
\end{tabular}

\section{HPTLC Analysis}

The ethanolic extract of PAVL extract indicated the presence of ten different types of flavonoids with $\mathrm{R}_{\mathrm{f}}$ values $0.06,0.16,0.29,0.39,0.56,0.83,0.91,0.96,0.98$ and 0.80 . It was confirmed that the presence of eleven different types of alkaloids with $\mathrm{R}_{\mathrm{f}}$ values $0.02,0.07,0.17,0.29,0.34,0.42,0.45,0.53,0.87,0.93$ and 0.41. The PAVL extract showed nine different types of steroids with $R_{\mathrm{f}}$ values $0.09,0.17,0.30,0.42$, $0.70,0.88,0.94,0.98$ and 0.41 . These results inferred that the extract showed flavonoids, alkaloids and steroids in it (Fig.-16) ${ }^{59}$. These analytical techniques indicated the presence of several functional groups namely $\mathrm{O}-\mathrm{H}, \mathrm{C}-\mathrm{H},-\mathrm{C} \equiv \mathrm{N}, \mathrm{C}=\mathrm{C}, \mathrm{C}-\mathrm{O}-\mathrm{C}, \mathrm{C}-\mathrm{O}$ etc that can act as an inhibitor. Aromatic compounds (which contain the $\mathrm{p}$ electrons) undergo particularly strong adsorption on many electrode surfaces ${ }^{60}$. The bonding can occur between the metal surface and the aromatic ring.

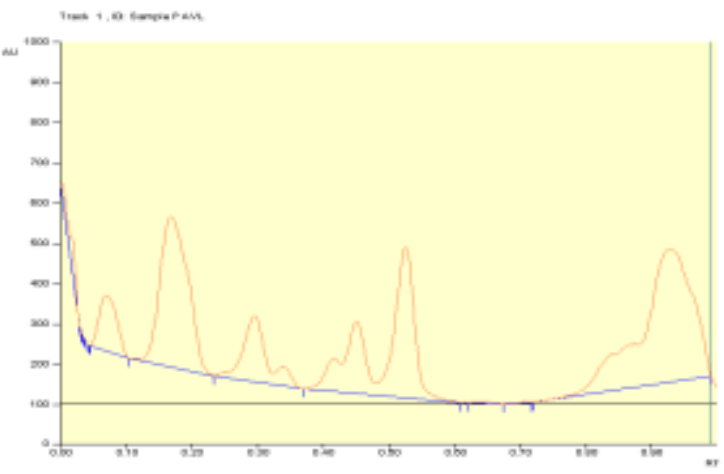

(a) PAVL -Baseline Display

(Scanned at UV 254nm)

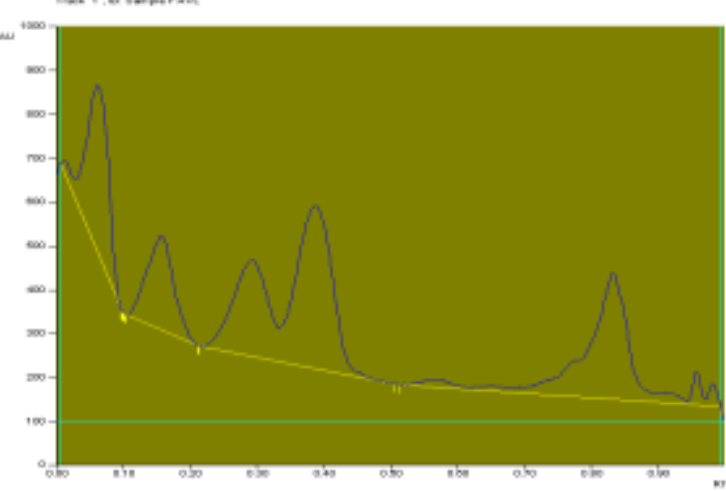

(c) PAVL -Baseline Display (Scanned at UV 366nm)

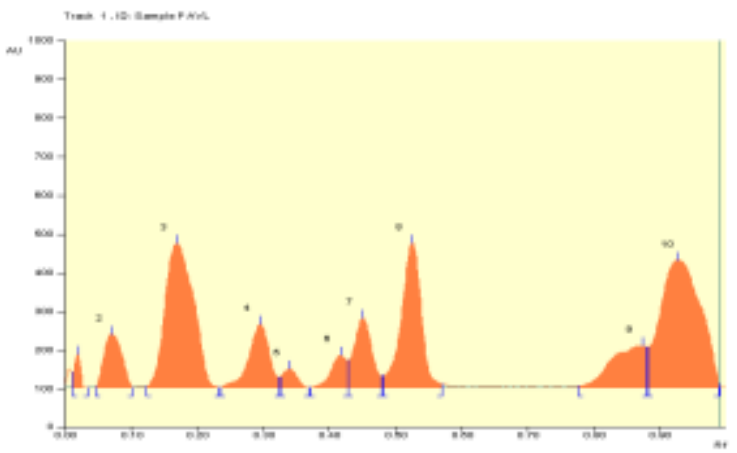

(b) PAVL -Peak Densitogram Display (Scanned at UV 254nm)

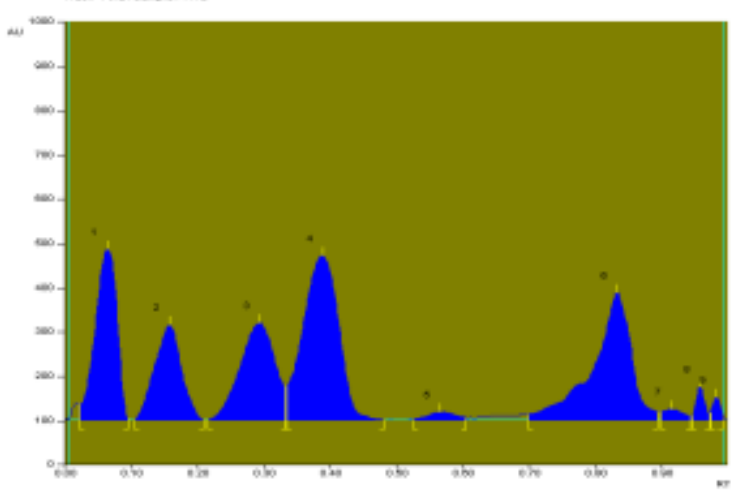

(d) PAVL -Peak Densitogram Display (Scanned at UV 366nm) 
RASĀYAN J. Chem.

Vol. 12 | No. 2 |431 - 449| April - June | 2019

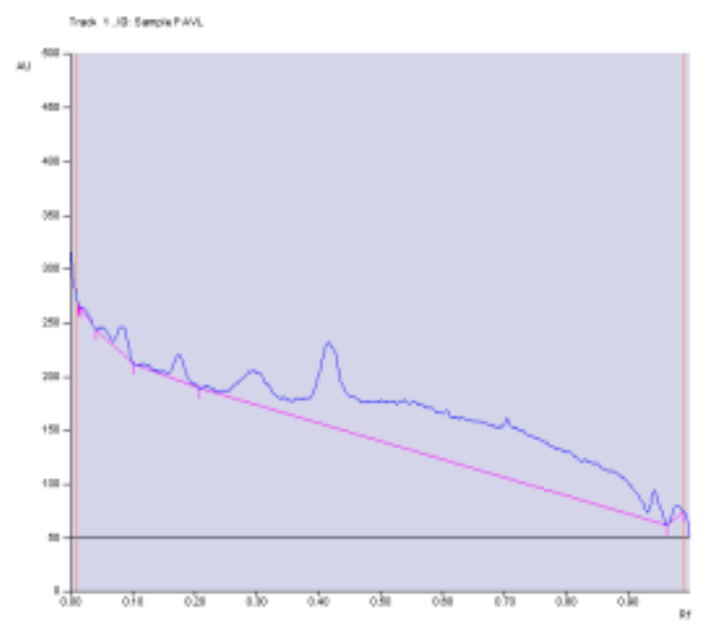

(e) PAVL -Baseline Display

(Scanned at UV 366nm)

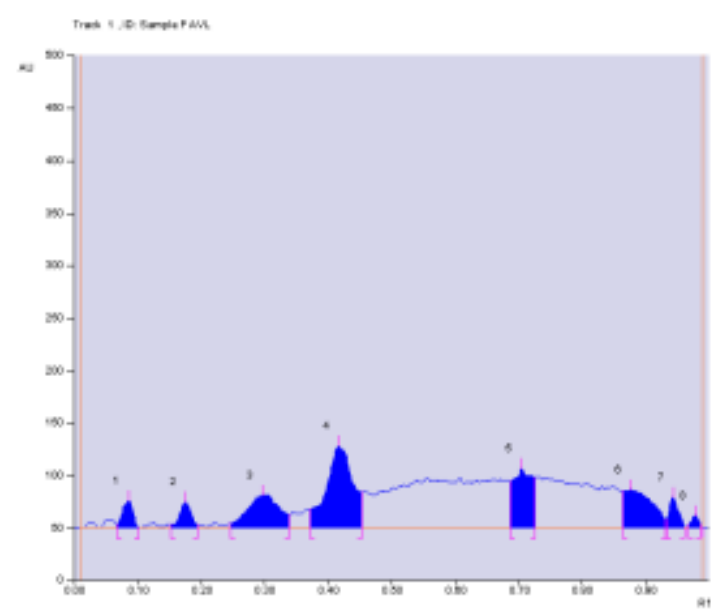

(f) PAVL -Peak Densitogram Display (Scanned at UV 366nm)

Fig.-16: HPTLC Analysis of (a, b) Flavonoid, (c, d) Alkaloid and $(e, f)$ Steroid of PAVL Methanolic Extract

The exact nature of the interactions between a metal surface and an aromatic molecule depends on the relative coordinating strength towards the given metal of the particular group present ${ }^{61}$. In aqueous acidic solution, PAVL exists either as a neutral molecule or as protonated molecules (cation). PAVL molecules might be adsorbed on the metal and acid solution interface in the following ways: (a) Electrostatic interaction of protonated molecules with already adsorbed chloride ions in the surface of MS (b) donoracceptor interactions between the vacant $d$ orbital of surface iron atoms and $p$-electron of the aromatic ring (c) interaction of unshared electron pairs of heteroatom with vacant d-orbital of iron surface atoms.

\section{CONCLUSION}

PAVL acted as an effective inhibitor for MS in $1 \mathrm{M} \mathrm{HCl}$ solution and the extent of inhibition efficiency was directly proportional to the concentration of the inhibitor. The inhibition efficiency increased with increased inhibitor concentration and the maximum IE of $97.1 \%$ was observed at $0.7 \%$ concentration of PAVL extract. The adsorption of the inhibitor followed Langmuir adsorption isotherm. From $\mathrm{I}_{\text {corr }}$ values maximum inhibition efficiency, $89.8 \%$ was obtained at $0.7 \%$ concentration of PAVL extract. Nyquist plots reflected that the charge transfer resistance values increased with increase in the concentration of PAVL extract. The inhibition efficiency (IE \%) measured from $R_{c t}$ values were found to be maximum at $0.7 \%$ concentration of PAVL extract. In the current investigation, the PAVL extract played a major role in reducing the metal dissolution as well as hydrogen evolution and protected the MS surface from corrosion.

\section{ACKNOWLEDGMENT}

The authors would like to thank the authorities of Avinashilingam Institute for Home Science and Higher Education for Women, Coimbatore-641043 and Tamilnadu, India for providing necessary facilities for carrying out this study.

\section{REFERENCES}

1. A.K. Mishra, N. Ebrahimi, D.W. Shoesmith and P.E. Manning, NACE Corrosion International Conference and Expo, 7680(2016)

2. A. Ostovari, S. M. Hoseinieh, M. Peikari, S. R. Shadizadeh and S. J. Hashemi, Corros. Sci., 51, 1935(2009), DOI: 10.1016j.corsci2009.05.024

3. M. Abdullah, A.Y. El-Etre, M.G. Soliman and E.M. Mabrouk, Anti-Corrosion Methods and Materials, 53,118(2006), DOI:10.1108/00035590610650820

4. P.R. Vijayalakshmi, R. Rajalakshmi and S. Subhashini, E-Journal of Chemistry, 7, 1055(2010) 
5. R. Rajalakshmi, S. Subhashini, S. Leelavathi and R. Femina Mary, Oriental Journal of Chemistry, 24,1085(2008)

6. P.R. Vijayalakshmi, R. Rajalakshmi and S. Subhashini, Asian Journal of Chemistry, 22, 4537(2010)

7. S. Subhashini, R. Rajalakshmi, A. Prithiba and A. Mathina, E-Journal of Chemistry, 7, 1133(2010)

8. P.R. Vijalakshmi, R. Rajalakshmi and S. Subhashini, Portugaliae Electrochimica Acta, 29, 9(2011), DOI: $10.4152 /$ pea.201101009

9. R. Rajalakshmi and S. Safina, E-Journal of Chemistry, 9,1632(2012)

10. R. Rajalakshmi and S. Safina, Asian Journal of Chemistry, 24, 4401(2012)

11. A. Mathina and R. Rajalakshmi, Rasayan Journal of Chemistry, 9(1), 56(2016).

12. S. Leelavathi and R. Rajalakshmi, NACE Corrosion Conference and Expo, 1-15(2013)

13. S. Leelavathi and R. Rajalakshmi, Journal of Materials and Environmental Science, 4, 625(2013)

14. A.Prithiba and R. Rajalakshmi, Hindawi Publishing Corporation, International Journal of Metals, 9 (2016), DOI:10.1155/2016/8579429

15. A. Prithiba and R. Rajalakshmi, Chem .Sci. Rev. Lett., 5, 83(2016)

16. D. Chassagne, J. Crouzet, C. L Bayonove and R.L. Baumes, J. Agric. Food Chem., 46, 4352(1998), DOI: $10.1021 / \mathrm{jf} 980416 \mathrm{k}$

17. A.Bendini , L. Cerretani, L. Pizzolante, T. Gallina-Toschi, F. Guzzo , S. Ceoldo, A. M. Marconi , F. Andreetta and M. Levi, Eur. Food Res. Technol., 223,102( 2006), DOI:10.1007/s00217-0050150-7

18. A.S. Patil, J. Medic. Plants Res., 4,1496(2010), DOI:10.5897/JMPR10.061

19. M. L. Zeraik and J. H. Yariwake, Microchemical Journal, 96, 86(2010), DOI: $10.1016 /$ j.microc.2010.02.003

20. S. S. Patel, H. Soni, K. Mishra and A. K. Singhai, Int. J. Res. Phytochem. Pharmacol, 1, 1(2011)

21. S. M. Zucolotto, C. Fagundes, F. H. Reginatto, F. A. Ramos, L. Castellanos, C. Duque and E.P. Schenkel, Phytochem. Anal., 23, 232(2012), DOI: 10.1002/pca.1348

22. M. P. Argentieri, M. Levi, F. Guzzo and P. Avato, J. Pharmacy Pharmacol., 67, 1603(2015), DOI: $10.1111 /$ jphp. 12454

23. K. C. Dos Santos, T. V. Borges, G. Olescowicz, F. K. Ludka, C. A. Santos and S. Molz, J. Pharm. Pharmacol, 68, 282(2016), DOI: 10.1111/jphp.12512

24. M. A. Farag, A. Otify, A.O. Porzel, C. G. Michel, A. Elsayed and L. A. Wessjohann Anal. Bioanal. Chem., 408, 3125(2016), DOI:10.1007/s00216-016-9376-4

25. K. H. Engel and R. Tressel, J. Agric. Food Chem. 39, 2249(1991)

26. M. Pontes, J. C. Marques and J. S. Camara, Microchem. J., 93, 1(2009), DOI: $10.1016 /$ j.microc.2009.03.010

27. N. Conde-Martinez, D. C. Sinuco and C. Osorio, Food Chem., 157, 356(2014), DOI: 10.1016/j.foodchem.2014.02.056

28. I.A. Chòez Guaranda, D. A. Herrera Hurtado, M. M. Martinez and P. I. Manzano Santana, Emirates J. Food Agric., 27, 650( 2015)

29. G. Buchbauer and L Jirovetz, J. Ess. Oil Res., 4, 329(1992)

30. ASTM G1-03, Standard practice for preparing, cleaning and evaluating corrosion test specimens, ASTM International, west Conshohocken, USA (2003)

31. ASTM International (ASTM), 100 Barr Harbor Dr., West Conshohocken, PA 19428 2959(1973)

32. J. B. Harborne, Phytochemical methods, London. Chapman and Hall, Ltd. pp. 49-188.

33. A. Fouda, S. H. Tawfik and A. H. Badr, Advances in Materials and Corrosion, 1(1), 1(2012)

34. K. Tebbji, N. Faska, A. Tounsi, H. Oudda, M. Benkaddour and B. Hammouti, Materials Chemistry and Physics, 106,260(2007), DOI: 10.1016/j.matchemphys.2007.05.046

35. A.K. Singh and M. A. Quraishi, Journal of Materials and Environmental Science, 1, 101(2010)

36. J. J. Fu, S. N. Li, Y. Wang and L. H. Cao, Journal of Materials Science, 45, 6255(2010), DOI: 10.1007/s10853-010-4720-0 
RASĀYAN J. Chem.

Vol. 12 | No. 2 |431 - 449| April - June | 2019

37. L. Ahamad, R. Prasad, and M. A. Quraishi, Corrosion Science, 52, 1472(2010), DOI:10.1016/j.corsci.2010.01.015

38. Messaouda Allaoui, Oumelkheir Rahim and Lakhdarsekhri, Oriental Journal of Chemistry, 33, 637 (2017), DOI: $10.13005 / \mathrm{ojc} / 330211$

39. U. F. Ekanem, S. A. Umoren, I. I. Udousoro and A. P. Udoh, Journal of Materials Science, 45 , 5558 (2010), DOI:10.1007/s10853-010-4617-y

40. A.Zerga, A. Attayibat, M. Sfaira, M. Taleb, B. Hammouti, M.E. Touhami and Z. Rais, Journal of Applied Electrochemistry, 40, 1575(2010), DOI:10.1007/s10800-010-0164-0

41. F. M. Donahue and K. Nobe, Journal of the Electrochemical Society, 112, 886(1965)

42. G. Moretti, F. Guidi and G. Grion, Corrosion Science, 46, 387(2004), DOI:10.1016/S0010938X(03)00150-1

43. N. O. Obi-Egbedi and I. B. Obot, Arabian Journal of Chemistry,6, 211(2013), DOI:10.1016/ j.arabjc .2010 .10 .004

44. A. Doner and G. Kardaş, Corrosion Science, 53,4223(2011), DOI: 10.1016/j.corsci.2011.08.032

45. H. Bourazmi, M. Tabyaoui, L. EL Hattabi, Y. El Aoufir, M. Taleb, J. Mater. Environ. Sci., 9, 928(2018), DOI:10.26872/jmes.2018.9.3.103

46. H. Gerengi and H. I. Sahin, Industrial \& Engineering Chemistry Research, 51, 780 (2012), DOI: $10.1021 / \mathrm{ie} 201776 \mathrm{q}$

47. S. S. Abd El Rehim, M. A. M. Ibrahim, and K. F. Khalid, Materials Chemistry and Physics, 70, 268(2001)

48. M. H. Hussin and M. J. Kassim, Materials Chemistry and Physics, 125, 461 (2011), DOI:10.1016/j.matchemphys.2010.10.032

49. E. E. Oguzie, D. I. Njoku, M. A. Chidebere, C. E. Ogukwe, and G. N. Onuoha, Industrial \& Engineering Chemistry Research, 53, 5886(2014), DOI:10.1021/ie404273f

50. A. Rodriguez-Torres, O. Olivares-Xometl, M.G. Valladares-Cisneros, J. G. Gonzalez-Rodriguez, Int. J. Electrochem.Sci., 13, 3023 (2018), DOI:10.20964/2018.03.40

51. A.Y. El-Etre, M. Abdullah and Z. El-Tantaury, Corros. Sci., 47,385(2005), DOI:10.1016/j.corsci.2004.06.006

52. A.Singh, E. E. Ebenso and M. A. Quraishi, M.A. Int. J. Electrochem. Sci, 7, 3409(2012)

53. M. Mobin, M. Rizvi, L. O. Olasunkanmi, and E. E. Ebenso, ACS Omega, 2, 3997-4008 (2017), DOI: $10.1021 /$ acsomega.7b00436

54. A. O. Okewale and A. Olaitan, International Journal of Materials and Chemistry, 7, 5(2017), DOI:10.5923/j.ijmc.20170701.02.

55. K. K. Alaneme, S. J. Olusegun and O. T. Adelowo, Alexandria Engineering Journal, 55, 673(2016), DOI: $10.1016 /$ j.aej.2015.10.009

56. T. K. Bhuvaneswari, V. S. Vasantha, C. Jayaprabha, Silicon, 10, 1793(2018), DOI:10.1007/s12633017-9673-3

57. G. E. Ugbabe, A. E. Ayodele, G. A. Ajoku, O. F. Kunle, I. Kolo and J. I. Okogun, Glob Res J., 1, 1(2010)

58. X. Li, S. Deng and H. Fu, Corrosion Science, 62, 163(2012), DOI:10.1016/j.corsci.2012.05.008

59. A.Gislaine, Silva and Carla and B. G. Bottoli, Critical Reviews in Analytical Chemistry, 45,76(2015), DOI: $10.1080 / 10408347.2014 .886937$

60. Y. Yetri, Gunawarman, Emriadi and J. Novesar, ARPN Journal of Engineering and Applied Sciences, 12,18, 5325-5332(2017).

61. I.M. Ritchie, S. Bailey and R. Woods, Adv. Colloid Interface Sci. 80,183(1999)

[RJC-5133/2018] 